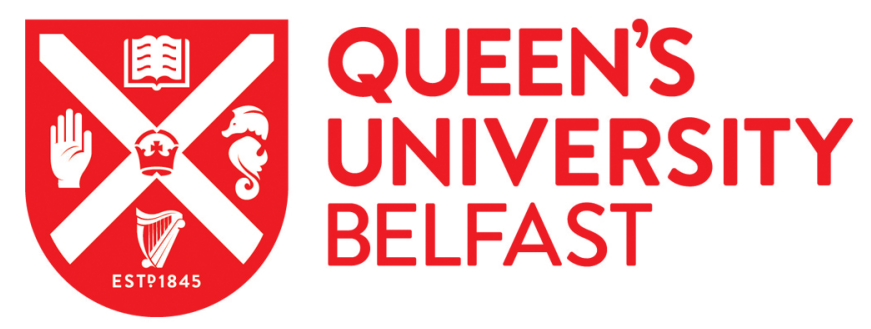

\title{
Future directions in International Financial Integration Research - A Crowdsourced Perspective
}

Lucey, B. M., Vigne, S., Ballester, L., Barbopoulos, L., Brzeszczynski, J., Carchano, O., Dimic, N., Fernandez, V., Gogolin, F., González-Urteaga, A., Goodell, J. W., Helbing, P., Ichev, R., Kearney, F., Laing, E., Larkin, C. J., Lindblad, A., Loncarski, I., Ly, K. C., ... Zaghini, A. (2018). Future directions in International Financial Integration Research - A Crowdsourced Perspective. International Review of Financial Analysis, 55, 35-49. https://doi.org/10.1016/j.irfa.2017.10.008

Published in:

International Review of Financial Analysis

Document Version:

Peer reviewed version

Queen's University Belfast - Research Portal:

Link to publication record in Queen's University Belfast Research Portal

\section{Publisher rights}

Copyright 2017 Elsevier

This manuscript is distributed under a Creative Commons Attribution-NonCommercial-NoDerivs License

(https://creativecommons.org/licenses/by-nc-nd/4.0/), which permits distribution and reproduction for non-commercial purposes, provided the author and source are cited.

\section{General rights}

Copyright for the publications made accessible via the Queen's University Belfast Research Portal is retained by the author(s) and / or other copyright owners and it is a condition of accessing these publications that users recognise and abide by the legal requirements associated with these rights.

Take down policy

The Research Portal is Queen's institutional repository that provides access to Queen's research output. Every effort has been made to ensure that content in the Research Portal does not infringe any person's rights, or applicable UK laws. If you discover content in the Research Portal that you believe breaches copyright or violates any law, please contact openaccess@qub.ac.uk. 


\title{
Future directions in International Financial Integration Research - A Crowdsourced Perspective
}

\author{
Brian M Lucey ${ }^{\mathrm{a}}$, Samuel A. Vigne ${ }^{\mathrm{b}}$, Laura Ballester ${ }^{\mathrm{c}}$, Leonidas \\ Barbopoulos $^{\mathrm{d}}$, Janusz Brzeszczynski ${ }^{\mathrm{e}}$, Oscar Carchanof ${ }^{\mathrm{f}}$, Nebojsa Dimic ${ }^{\mathrm{g}}$, \\ Viviana Fernandez ${ }^{\mathrm{h}}$, Fabian Gogolin ${ }^{\mathrm{i}}$, Ana González-Urteaga ${ }^{\mathrm{j}}$, John W. \\ Goodell $^{\mathrm{k}}$, Pia Helbing ${ }^{\mathrm{l}}$, Riste Ichev ${ }^{\mathrm{m}}$, Fearghal Kearney ${ }^{\mathrm{n}}$, Elaine Laing ${ }^{\mathrm{o}}$, \\ Charles J. Larkin ${ }^{\mathrm{p}}$, Annika Lindblad ${ }^{\mathrm{q}}$, Igor Lončarski ${ }^{\mathrm{r}}$, Kim Cuong Ly ${ }^{\mathrm{s}}$, \\ Matej Marinč ${ }^{\mathrm{t}}$, Richard J. McGee ${ }^{\mathrm{u}}$, Frank McGroarty ${ }^{\mathrm{v}}$, Conor Neville ${ }^{\mathrm{w}}$, \\ Martha O'Hagan-Luff ${ }^{\mathrm{x}}$, Vanja Piljak ${ }^{\mathrm{y}}$, Aleksandar Sevic ${ }^{\mathrm{z}}$, Xin Shengaa, \\ Dimitrios Stafylas $^{\mathrm{ab}}$, Andrew Urquhart ${ }^{\mathrm{ac}}$, Roald Versteeg ${ }^{\mathrm{ad}}$, Anh N Vu ${ }^{\text {ae }}$, \\ Simon Wolfe ${ }^{\text {af }}$, Larisa Yarovaya ${ }^{\text {ag }}$, Andrea Zaghini ${ }^{\text {ah }}$ \\ ${ }^{a}$ Trinity Business School, Trinity College Dublin, Dublin 2, Ireland \\ email: blucey@tcd.ie \\ ${ }^{b}$ Queen's Management School, Queen's University Belfast, BT9 5EE, Northern Ireland, \\ United Kingdom \\ email:s.vigne@qub.ac.uk (corresponding author) \\ ${ }^{c}$ Faculty of Economics, Department of Financial Economics, University of Valencia, Av. \\ Los Naranjos s/n, Valencia, Spain \\ email: laura.ballester@uv.es \\ ${ }^{d}$ University of Glasgow, University Avenue, Glasgow G12 8QQ, UK \\ email: leonidas.barbopoulos@glasgow.ac.uk \\ ${ }^{e}$ Newcastle Business School (NBS), Northumbria University, Newcastle-upon-Tyne, \\ United Kingdom \\ email: janusz.brzeszczynski@northumbria.ac.uk \\ ${ }^{f}$ Faculty of Economics, Department of Financial Economics, University of Valencia, Av. \\ Los Naranjos s/n, Valencia, Spain \\ email: oscar.carchano@uv.es \\ ${ }^{g}$ University of Vaasa, Department of Finance and Accounting, Vaasa, Finland \\ email: dnebojsa@uva.fi \\ ${ }^{h}$ School of Business, Universidad Adolfo Ibanez, Santiago, Chile \\ email: viviana.fernandez@uai.cl \\ ${ }^{i}$ Queen's Management School, Queen's University Belfast, BT9 5EE, Northern Ireland, \\ United Kingdom \\ email: f.gogolin@qub.ac.uk \\ ${ }^{j}$ Public University of Navarre, Arrosadia Campus, 31006, Pamplona, Spain \\ email: ana.gonzalezu@unavarra.es \\ ${ }^{k}$ College of Business Administration, University of Akron \\ email: johngoo@uakron.edu \\ ${ }^{l}$ Trinity Business School, Trinity College Dublin, Dublin 2, Ireland \\ email: helbingp@tcd.ie
}


${ }^{m}$ Faculty of Economics at the University of Ljubljana, Kardeljeva pl. 17, Ljubljana, Slovenia, email: risteicev@yahoo.com

${ }^{n}$ Queen's Management School, Queen's University Belfast, BT9 5EE, Northern Ireland, United Kingdom

email: f.kearney@qub.ac.uk

o Trinity Business School, Trinity College Dublin, Dublin 2, Ireland email: elaing@tcd.ie

${ }^{p}$ Trinity Business School, Trinity College Dublin, Dublin 2, Ireland email: larkincj@tcd.ie

${ }^{q}$ University of Helsinki, HECER, Department of Political and Economic Studies, Helsinki, Finland email: annika.lindblad@helsinki.fi

${ }^{r}$ Faculty of Economics at the University of Ljubljana, Kardeljeva pl. 17, Ljubljana, Slovenia, email: igor.loncarski@ef.uni-lj.si

${ }^{s}$ School of Management, Swansea University, Swansea SA1 8EN, United Kingdom email: k.c.ly@swansea.ac.uk

${ }^{t}$ Faculty of Economics at the University of Ljubljana, Kardeljeva pl. 17, Ljubljana, Slovenia, email: matej.marinc@ef.uni-lj.si

${ }^{u}$ Centre for Digital Finance, Southampton Business School, University of Southampton, Southampton, SO17 1BJ, United Kingdom email: rjm1y13@soton.ac.uk

${ }^{v}$ Centre for Digital Finance, Southampton Business School, University of Southampton, Southampton, SO17 1BJ, United Kingdom email:f.j.mcgroarty@soton.ac.uk

${ }^{w}$ Trinity Business School, Trinity College Dublin, Dublin 2, Ireland email: cneville@tcd.ie

${ }^{x}$ Trinity Business School, Trinity College Dublin, Dublin 2, Ireland email: ohaganm@tcd.ie

${ }^{y}$ University of Vaasa, Department of Finance and Accounting, Vaasa, Finland email: vanja.piljak@uva.fi

${ }^{z}$ Trinity Business School, Trinity College Dublin, Dublin 2, Ireland email:a.sevic@tcd.ie

${ }^{a a}$ Huddersfield Business School, University of Huddersfield, Huddersfield, HD1 3DH, United Kingdom email: x.sheng@hud.ac.uk

${ }^{a b}$ Aston Business School, Aston University, Birmingham B4 7ET, UK email: d.stafylas@aston.ac.uk

${ }^{a c}$ Centre for Digital Finance, Southampton Business School, University of Southampton, Southampton, SO17 1BJ, United Kingdom email: aju1y12@soton.ac.uk

${ }^{a d}$ Department of Economics, Mathematics, and Statistics, Birkbeck College, University of London, London, United Kingdom 
email: r.versteeg@bbk.ac.uk

ae School of Business, Management and Economics, University of Sussex, UK email:A.Vu@sussex.ac.uk

${ }^{a f}$ Centre for Digital Finance, Southampton Business School, University of Southampton, Southampton, SO17 1BJ, United Kingdom

email: ssjw@soton.ac.uk

${ }^{a g}$ Lord Ashcroft International Business School, Anglia Ruskin University, Chelmsford, $U K$

email: larisa.yarovaya@anglia.ac.uk

${ }^{a h}$ Banca d'Italia, DG-Economics, Statistics and Research, Rome, Italy

email: andrea.zaghini@bancaditalia.it

\begin{abstract}
This paper is the result of a crowdsourced effort to surface perspectives on the present and future direction of international finance. The authors are researchers in financial economics who attended the INFINITI 2017 conference in the University of Valencia in June 2017 and who participated in the crowdsourcing via the Overleaf platform. This paper highlights the actual state of scientific knowledge in a multitude of fields in finance and proposes different directions for future research.
\end{abstract}

Keywords: Financial Economics, Crowdsourcing, Literature Review, Financial Research 


\section{Contents}

1 The Present State of International Financial Integration 5

1.1 The effect of the Global Financial Crisis on International Financial Integration . . . . . . . . . . . . . . . 5 5

1.2 Policy related integration responses to the Global Financial Crisis . . . . . . . . . . . . . . . . 6

1.3 Recent advances in Measuring International Financial Integration ........................ 11

2 Sectoral Research Responses to the Challenge 16

2.1 Banking, loan and Deposit Markets . . . . . . . . . . . 16

2.2 Equity Markets . . . . . . . . . . . . . . . . . . 18

2.3 Government Bond Markets . . . . . . . . . . . . . . 23

2.4 Corporate Bond Markets . . . . . . . . . . . . . . . 25

2.5 Equity Markets Integration . . . . . . . . . . . . . . . 27

2.6 Commodity Markets . . . . . . . . . . . . . . . . . . 29

2.7 Risk Management . . . . . . . . . . . . . . . . . . . . 30

2.8 FinTech . . . . . . . . . . . . . . . . . 31

2.9 Alternative Investments . . . . . . . . . . . . . . . . 32

2.10 Bank liquidity . . . . . . . . . . . . . . . . . . . . . . . . . . . . . . . . . . . . 33

2.11 Derivatives Markets . . . . . . . . . . . . . . . 34

2.12 Financial market wide dependences . . . . . . . . . . . 38

$\begin{array}{lll}3 & \text { Conclusion } & 39\end{array}$ 


\section{The Present State of International Financial Integration}

\subsection{The effect of the Global Financial Crisis on International Financial In- tegration}

The onset of the Global Financial Crisis and the subsequent response by monetary authorities, in particular in developed countries, has brought about several major changes to debt markets. First, there has been a significant drop in cross-border bank lending, in particular in the interbank lending (see for example James et al. (2014) and Batten et al. (2013)) from around USD 12 trillion at the peak in mid 2008 to around USD 7 trillion 5 years into the crisis. On the other hand, cross-border bank lending to nonfinancial corporations has been rather stable. Second, the majority of the decline has been related to the lending between developed economies, in particular within Europe. Contrary to that, cross-border lending to emerging economies has increased by almost 50 percent in the same period. Third, similar developments can be observed in terms of portfolio flows, where annual debt flows are at around half of what they used to be prior to the Global Financial Crisis. Again, there is a stark contrast between developed and emerging markets, where post crisis there has been a major increase in portfolio flows, both equity and debt, to emerging economies. These developments indicate an important and non-transitory post crisis shift in the financial integration "channel" from an institutional to a more market-based one, as well as a looser integration amongst the largest developed economies and an increasing integration between developed and emerging markets. Finally, an important post crisis development relates to the composition and the ownership of debt assets. Flight to quality and massive interventions of monetary authorities raised the importance of government issued securities, in particular in more advanced economies. As shown by Lane and MilesiFerretti (2017), Euro area countries most severely affected by the Global Financial Crisis exhibit a declining share of foreign government debt owners, while the opposite holds for the large core Euro area countries. As expected, they also show that foreign share rises with the growth rate of the economy and the reduction of capital controls. The negative relation between foreign share and central bank holdings in the case of advanced economies suggests funnelling and concentration of major risks.

Higher level of financial market integration should be followed by lowering the cost of capital, increasing investment opportunities, and increasing economic growth via international risk sharing (Bekaert and Harvey (2003)). 
However, the high level of financial integration means also higher sensitivity to global financial crises. In this light, Lehkonen (2015a) examines the effect of the 2007-2009 global financial crisis on financial integration and finds that the effect differs amongst developed and emerging markets. In particular, the integration increased slightly for emerging markets but decreased for developed markets during the crisis. Yarovaya et al. (2016) analysed the patterns of intra- and inter-regional return and volatility across 10 developed and 11 emerging markets in Asia, the Americas, Europe and Africa using both stock indices and stock index futures in the period from 2005 to 2014. The results report the increase of interconnectedness between markets during the Global Financial Crisis and the Eurozone debt crisis. Yarovaya et al. (2016) claim that markets are more susceptible to domestic and regionspecific volatility shocks than to inter-regional contagion. Thus for european and american investors the best devirsification opportunities can be offered by emerging markets from Asia. The study by Yarovaya and Lau (2016) analyses the benefits of portfolio diversification available to UK investors in emerging BRICS and MIST markets using conventional and regime-switch cointegration techniques; results suggest an absence of diversification benefits in the majority of seleceted emerging markets, while the most attractive direction for invesments remains the Chinese financial market. The analysis of decoupling and contagion hypotheses become increasingly popular in integration literature - the aim of this stream of literature is to identify markets that can act as safe havens during crisis episodes. For example, the research by Hkiri and Yarovaya (2017) demonstrates the decoupling of the Islamic indices from their conventional counterparts during turbulent periods. Hkiri and Yarovaya (2017) utilise daily data of nine regional Islamic stock indices and their conventional counterparts for the period between 1999 and 2014 providing evidence that Islamic financial indices are a safe haven for investors during financial crises.

\subsection{Policy related integration responses to the Global Financial Crisis}

The political system came up with a series of responses at the national and transnational level. The G20 developed an international response with the creation of the Financial Stability Board. The introduction of the Basel III treaty by the G20 and the move to create a banking union by the European Union were all immediate responses. The United Kingdom has followed an independent monetary and financial regulatory policy relative to the US and the European Union. The Financial Services (Banking Reform) Act 2013 
is an example of this cleaving of the UK regulatory structure. That independence can be seen as a function of policy cyclicality, something that the Bank of England is acutely aware of as it tries to telescope the decades and centuries to learn more about preventing policy failures. This long perspective was not present in the US Dodd-Frank Act from 2010 that addressed past failures and added complexity (Dudley (2017)). The parliamentary process has not yet created enough change in culture, power distribution or equitable remedy. The recent behavioural finance programme begun by the NY Federal Reserve, aimed at improving banker habits, is a reflection of the limits of Dodd-Frank.

At present our esteemed colleagues of the legal profession have forged new and interesting approaches to the crisis. These startle economists and terrify financiers, such as the newly proposed German Abwicklungsmechanismusgesetz to implement the Single Resolution Mechanism. The response has been different forms of populism in different contexts. In the US the rise of Senator Elizabeth Warren was a response to the failures of the DoddFrank Act and the partisan bickering that accompanied the publication of the Financial Crisis Investigation Committee report in 2011 (including the Peter Wallison externally published dissent). In the European context, the rise of figures such as the Former Greek Finance Minister Yanis Varoufakis and subsequently Brexit and the election of President Trump illustrates an environment where the traditional post-war political consensus is becoming threadbare. While this is not the focus of this paper, it is something that all parliamentarians have become conscious of during the past 24 months. The results in Spain, Greece, France and in the European Parliament highlighted that the bedrock of the European project, especially in the grand consensus EPP party, illustrate that business as usual is under concerted attack.

While that may be considered collateral damage to an economist or technocrat as part of the process of good government or ensuring that central banking does not become a crude instrument of the political business cycle, it does not mean that the political system will not look to intervene. It is clear that the position of the national and supranational central bank, something which makes up a large part of the Banking Inquirys questioning, is under examination. In the US the Fed has become the political lightning rod. The response has been a clear questioning of the role of the lender of last resort. Who has the power to deploy it, who has the access to it and what countermeasures are meant to accompany it at point of request? The unfortunate conclusion so far has been that the Lombard Street understand- 
ing of the lender of last resort has an unusual complication - the ability to maintain a structure that is a lender of last resort relies upon it never being required. Like the sting of the honeybee, the act of defending the financial system is suicidal, for to use it will violate the uneasy arrangement between the political classes and the technocrats. While this has seen swift rebuke in the form of the US legislative environment it is only forming into a policy position in Europe as the new Banking Union structures work their way into national laws.

Independent central banks would protect the currency from political manipulation of the sort that destroyed so many economies in the present (such as Argentina) and in the past (an example being Germany). In exchange for such freedom central banks must be highly transparent and accountable to parliament generally. In Ireland, Section 42 of the Freedom of Information Bill 2013 exempts from Freedom of Information "any of the supervisory directives within the meaning of the Central Bank Act 1942". In rejecting an amendment to counteract this secrecy the Minister stated that this was a requirement of the European Central Bank. In this situation, the occlusion of the banking sector from external scrutiny is not only facilitated by an official body but required to be incorporated into the national body of law. Article 33AK of the Central Bank Act 1942 precludes any form of date, individual, firm or decision identifiable notes to be produced from the materials provided the Central Bank of Ireland to any public or non-criminal enquiry.

The challenge is that while this is taking place, reviews, such as the Banking Inquiry have no input and national parliaments have limited scrutiny over the implementation of the new laws. That does not mean that the Financial Trilemma of Financial Stability, International Banking, and National Financial Policies has disappeared. It has migrated to a more pliable space, in the public discourse, within the organisations themselves and in the courts. The role of the German Constitutional Court in Karlsruhe has been considered of the utmost importance to the evolution of the economic constitution of Europe. The Irish case brought by Thomas Pringle (Thomas Pringle vs. Government of Ireland and the Attorney General C-370/12) before the court of First Instance was one of the rare instances where a European national, in this case a sitting member of parliament, questioned the speed and direction of travel of the undebated economic constitution of Europe. The outline of the economic constitution of the European Union and the Eurozone by Advocate General Kokott was the first statement of the new framework constructed through the Brownian motion of crisis meetings in Brussels. Im- 
portantly, except for the high officials and the highest ministers of cabinet, all this had been presented as a fait accompli to parliaments of Europe.

Culture matters in the context of the policy response. The quality of financial formal record keeping has come under scrutiny in many jurisdictions following the GFC. There are no consistent written records or minutes detailing the opinions of various stakeholders or a formal analysis weighing the pros and cons of the guarantee and nationalisation decisions (Nyberg (2011)). This lack of information severely limits our ability to understand the rational of the decision-making and the factors considered in the process. Without such critical information, it is hard to assess any flaws in the rational or analysis conducted by the government. According to Finnish economist Peter Nyberg, "the possibility that they might experience catastrophic losses in asset values into the future does not appear to have been given serious consideration even from a contingency policy point of view" (Nyberg (2011)). Concurrent with other academic and professional analyses of the crisis, we also contend that the blanket guarantee and inclusion of subordinate debt was overly broad. Granted, we acknowledge the supreme difficulty of decision-making while the crisis was unfolding. Based on the three central papers documenting the response and management of the crisis (Regling and Watson (2010), Honohan et al. (2010), and Nyberg (2011)), it is apparent that there was a clear misinterpretation of the ongoing crisis as an issue of liquidity as opposed to overall solvency. As discussed by Nyberg, "there appears to have been no fears and, at most, a modest discussion on possible underlying acute solvency problems. This is true of the banks themselves as well as of the authorities" (Nyberg (2011)). Thus, the decision to guarantee all debt stemmed from a fundamental misunderstanding of the crisis at hand. The specific underpinning of this lack of information will be further explored later in this analysis. A key and unique aspect of the Irish bailout was the decision to guarantee dated subordinate debt. In fact, the inclusion of such debt "[...] was not necessary in order to protect the immediate liquidity position" (Honohan et al. (2010)). The two primary arguments in support of inclusion centered on the idea that doing so would help banks open new bonds and enhance the simplicity of the intervention as a whole. The first point is open to debate, but Honohan et al. (2010) argues that such a guarantee puts undue stress on the sovereign, potentially impacting the domestic bond market and thus current sovereign bondholders. The second point, however, lacks any firm theoretical basis. The decision to draw the line between the liabilities that would be backed and those that would not 
was, according to Honohan et al. (2010), "arbitrary". The guarantee was also broader than other comparable actions taken by other sovereign governments. For example, the Northern Rock guarantee only extended to existing deposits (Honohan et al. (2010)). The European Commission responded with a change in policy in their 2013 Banking Communication (European Commission (2013)).

All of the analysis emerging from the crisis has been unequivocally critical of principles based regulation and moral suasion. As stated in the Report on the Crisis in the Domestic Banking Sector, "a belief in principles-based regulation caused the Financial Regulator to rely excessively on process over outcomes. It engendered an unwarranted degree of complacency about the likely performance of well-governed banks" (House of the Oireachtas Committee of Public Accounts). From the Honohan et al. (2010) report: "In sum, the moral suasion approach appeared to have been entirely ineffective in terms of inducing any significant change in institutions lending behaviour". While the initial principle behind efficient and streamlined regulation to promote economic growth may have been advantageous, the strategy facilitated a toxic level of complacency that lead the financial regulatory bodies to actively ignore warnings signs throughout the economy: as a result of this approach, zero fines or penalties were enacted from 2003 to 2008 for numerous breaches of corporate governance and regulatory principles and rules (Honohan et al. (2010)).

Better stress testing is a key area where a more thorough empirical approach is both warranted and necessary. Stress tests are processes put in place to simulate various economic phenomena to see if a banks portfolio can sustain downturns in the macro economy. For example, a stress test will evaluate how loans will perform if the economy contracted over a twoyear period to analyse the extent to which a bank is prepared for various potential changes in the global system. Stress-testing processes by financial regulatory bodies suffered from two primary shortcomings. First, they overly relied on findings produced internally by financial institutions as opposed to rigorously exploring the data independently. Second, the analyses focused on the most likely scenarios to emerge during the time period analysed, when the goal of a stress test is the exact opposite. Indeed, the very motivation of a stress test is to understand what happens to a portfolio or position when an unlikely event occurs - widespread contraction or collapses in asset prices. Analysis conducted by financial institutions and regulatory bodies focused on likely outcomes as opposed to low-probability events that ended 
up occurring (Honohan et al. (2010)). In statistical terms, the tail-events were ignored on the distribution, leading to a substantial misunderstanding of risk; another problem with the stress tests deployed were that every bank was using completely different models that varied dramatically in rigour and effectiveness (Honohan et al. (2010)). Though there is no perfect mechanism that can foresee all macroeconomic risk - we can and must do better than the lax processes in place before and during the financial crisis.

A key theme throughout the literature reviewing the financial crisis was the continued problems that arose due to the fragmented nature of the financial regulatory system. Confusion and dissension over the scope and jurisdiction of the Central Bank of Ireland (CB), the Irish Financial Services Regulatory Authority (FR), and the Department of Finance (DoF) lead to huge gaps in the regulatory policy structure, resulting in crucial shortcomings in terms of micro and macro prudential supervision of the financial sector. According to Nyberg (2011), "One possible consequence of this silo think was that the DoF, discouraged from interfering in the work of the independent FR and CB, remained seriously underweight in professional financial expertise and engagement. The Commission considers it likely that the lack of overall analysis and responsibility in so many Irish public institutions may have allowed a number of warning signs to remain undetected".

The subject of regulatory structure was addressed in the Central Bank Reform Act of 2010. The bill, amongst other changes, consolidated the financial regulatory structure under the newly formed Central Bank Commission. The Central Bank Commission now has responsibility for the totality of financial regulatory activity, with two different Directors responsible for macroeconomic stability and microprudential regulatory operations. While we applaud the fact that such a regulatory structure should hopefully strengthen communication, information sharing, and efficiency, such a structure also carries risk. It is important that penalties assessed during consumer protection functions are not subordinated due to the potential risk of destabilising a financial institution. Ensuring that both mandates are carried out effectively is a challenge that is perhaps exacerbated in a consolidated regulatory environment.

\subsection{Recent advances in Measuring International Financial Integration}

Financial globalisation has significantly increased during the last few decades. The increased integration of the financial systems has involved 
greater cross-border capital flows, tighter and more stable links amongst financial markets, and greater presence of foreign financial firms around the world. Indeed, many of the standard aggregate measures of financial globalisation such as gross capital flows, stocks of foreign assets and liabilities, and degree of co-movement of returns suggest that international financial integration has become widespread and has reached unprecedented levels (Watson (1999)).

As the integration of the financial markets is not a uniform process that significantly progressed in time, many studies analyse integration utilising various estimation periods and varying country selections, providing evidence from different methodologies. Due to the fact that integration is a dynamic process, it is challenging to measure it. The study by Kearney and Lucey (2004) discussed different approaches to the investigation of integration. There are two main categories of measures that can be used to evaluate the integration of financial markets: direct measures and indirect measures. The first approach, in other words direct measures, suggests evaluating the extent to which the rate of returns of financial assets, with the same maturity and risk characteristics, are equalised across financial markets. The direct measures approach is based on the so-called law of one price, following the logic that the lessening of regulatory barriers between markets will cause the distribution of capital flows to the most attractive asset classes across the globe, consequently equalising the returns on the assets with the same risk characteristics. However, the main challenge of this approach to measuring integration is to identify assets that are sufficiently homogenous in terms of their risk profiles to make an adequate comparison of the equalisation of financial markets (Kearney and Lucey (2004)).

Kearney and Lucey (2004) further divide the literature on financial integration into three categories, testing:

- The segmentation of equity markets via the international CAPM; examples can be found in Bekaert and Hodrick (1992), Campbell and Hamao (1992), and Errunza and Padmanabhan (1992).

- The extent, and determinants, of changes in the correlation or cointegration structure of the markets; examples being Bernard (1991); Gilmore and McManus (2002).

- Time-varying measures of integration: Aggarwal and Muckley (2003), Barari (2004), Bekaert and Harvey (1995), Birg and Lucey (2006), 
Forbes and Rigobon (2002), Longin and Solnik (1995), and Sheng et al. (2017).

While the first two categories demonstrate limited attempts to measure the time-varying nature of integration, the third category uses more sophisticated methodologies to capture the dynamic linkages between markets.

In a related stream of literature, Ibrahim and Brzeszczynski (2009, 2014) propose a Foreign Information Transmission (FIT) model, which captures time-varying nature of interdependence relationships amongst markets and allows for variation of parameters over time.

Financial market integration is one of the central themes in international finance and it represents the broader concept of the complex interrelationships amongst different financial markets. One specific dimension of financial integration is related to the concept of co-movement across financial markets and is interpreted in terms of the nature and extent of interdependences across asset returns (Kim et al. (2006)). The literature on the co-movements amongst international financial markets is very extensive. In the vein of two main financial asset classes, equity and bonds, the literature can be generally classified into three main streams:

- The first stream examines different aspects of equity market co-movement dynamics, where examples can be found in Bessler and Yang (2003), Brooks and Del Negro (2004), Graham and Nikkinen (2011), Kim et al. (2005), Kiviaho et al. (2014), and Longin and Solnik (2001).

- The second stream focuses on stock-bond co-movement in a single country or multi-country context; see Andersson et al. (2008), Baur and Lucey (2009), Cappiello et al. (2006), Connolly et al. (2005), Dimic et al. (2016), Panchenko and Wu (2009), and Yang et al. (2009).

- Finally, the third stream focuses on the co-movement amongst international bond markets; examples can be found in Kumar and Okimoto (2011), Lucey and Steeley (2006), Piljak (2013), Smith (2002), and Yang (2005).

An additional stream of related literature concentrates on determinants of financial integration. In the vein of equity markets integration, the earlier studies indicated that macroeconomic factors (business cycle fluctuations, the inflation environment, and monetary policy stance) play important roles 
in explaining equity market co-movement dynamics; see for example Arajo (2009), Cai et al. (2009), Dumas et al. (2003), and Syllignakis and Kouretas (2011).

More recently, financial liberalisation, the institutional environment, and global financial uncertainty have been identified as important determinants of financial integration (see Lehkonen (2015b)).

Financial integration can be measured in three dimensions: the global, national, and regional integration (Reddy (2002)). Global financial integration involves opening up the markets and financial institutions to free cross-border financial services and the flow of capital. Additionally, barriers such as capital controls, withholding taxes, and obstacles to the movement of technology and people are removed. One of the goals of global integration is to balance the national standards and laws across countries. The second dimension of integration is regional financial integration. Regional integration arises due to ties between the countries in a certain geographic region. It is far more achievable than global financial integration due to the tendency of markets to concentrate in a certain geographical center. Regional integration is important for national economies because it also promotes the development of domestic financial markets. The most easily attainable dimension of integration happens at the domestic level. Domestic financial integration involves the linkage of different domestic financial segments. Some financial institutions, such as intermediaries, help to accelerate this integration due to their business operating concurrently in two or more market segments (e.g. commercial banks work with savings and loan markets simultaneously).

Most of the studies on the equity market integration provide evidence of the increasing integration in the recent two decades, there is, however, no consensus in the literature on a well-accepted measure of integration (Pukthuanthong and Roll (2009)). Following early studies on market integration, several recent papers further advanced the literature on measuring market integration, such as Arouri et al. (2012), Bekaert et al. (2011), Carrieri et al. (2007), Chambet and Gibson (2008), Lehkonen (2015b), and, as mentioned earlier, Pukthuanthong and Roll (2009)).

In particular, Carrieri et al. (2007) propose a new integration measure derived from a static asset pricing model in which expected equity returns are linked to local and global risk factors (variances and covariances) and prices of risk. Their model allows risk factors and prices of risk to vary through time. Chambet and Gibson (2008) propose a model that includes global and local factors plus a systematic emerging market factor as a measure of 
financial integration. Their financial integration measure is also enriched by adding indicators of real activity (trade openness and trade concentration). Pukthuanthong and Roll (2009) use a multi factor model for country equity returns to derive a new integration measure based on an adjusted $R^{2}$ from a multi-factor model.

Berger and Pukthuanthong (2012) further expand the framework of financial integration analysis highlighted in Pukthuanthong and Roll (2009) by providing an estimate of systemic risk within international equity markets. Their propose a market fragility index, which is a risk measure that recognises periods of systemic risk and therefore, high levels of the market fragility index indicate an increased possibility of a global financial crash. Lehkonen (2015b) applies the same measure developed by Pukthuanthong and Roll (2009), but expands the analysis by examining the relationship between the recent global financial crisis and global market integration. His study provides evidence that although equity market integration has increased over the past three decades, the integration pattern differs amongst developed and emerging markets (integration has increased slightly for emerging markets but decreased for developed countries during the crisis). Bekaert et al. (2011) develop a new measure of the degree of equity market segmentation. Their measure is based on industry-level earnings yield differentials (relative to world levels) aggregated across all industries in a given country. Arouri et al. (2012) propose a theoretical testable capital asset pricing model for partially segmented markets. More recently, Cordella and Ospino Rojas (2017) propose a new measure of financial globalisation: the Financial Globalization Index (FGI). This new measure is an asset price correlation measure based on Pukthuanthong and Roll (2009). The novel aspect of proposed measure relative to Pukthuanthong and Rolls measure is that Cordella and Ospino Rojas (2017) consider the fact that changes in the correlation between different countries stock markets partly reflect changes in global volatility and they account for those changes.

Some studies within the markets integration literature also investigated the patterns of geographical changes in relative influence of financial markets over time, in particular from the perspective of the evolution of their mutual interdependence in the periods before and after the 2007 Global Financial Crisis. For example, Ibrahim et al. (2017) analysed this problem for the data from the stock markets in three main geographical regions of Europe, USA and Asia using the Foreign Information Transmission (FIT) model (Ibrahim and Brzeszczynski (2009)) to capture both the direct and the indirect chan- 
nels of stock-return signal-transmission mechanisms across the three major geographical securities trading centres in London, New York and Tokyo. The results provided by Ibrahim et al. (2017) indicate that the influence of the US market has weakened after the Global Financial Crisis, while the role of the main trading centres of the other two regions in Europe and Asia has strengthened over time. These findings are consistent with the concept of a geographical shift in the balance of economic powers between countries and they open up a new avenue for future inter-disciplinary research at the intersection of such fields as: finance, economics, political science and economic geography. Sheng et al. (2017) also report some interesting geographical patterns in the return transmission mechanism across eight major international stock markets. While considering the nature of motives to trade underlying the given price movements, they find that trades originating in Asia are more likely to be information-based, those originating in America tend to be liquidity-based, and those originating in European markets are a mixture of these two types.

\section{Sectoral Research Responses to the Challenge}

\subsection{Banking, loan and Deposit Markets}

Friedman (1970) professes that a company should only have one social responsibility which is to maximise shareholders wealth in a legal manner. He believes this sole responsibility is substantial as the profits and wealth generated would eventually find their own way to help the public, while improving the shareholders monetary circumstances. Fama and French (2002) believe that high gearing is negatively correlated to profitability. Accordingly this does not support the trade-off theory and its strong emphasis on debt finance. In fact Drobetz and Fix (2005) also announce that profitable firms tend to posses low leverage, due to the fact that high debt levels are strongly associated with volatility of a companys potential earnings. Kayhan and Titman (2007) declare that numerous companies that posses low gearing have high profitability because of the passive accumulation of profits. Therefore if the pecking order only promotes low leverage through association then it must be acknowledged that this could be overlooked quite easily. Indeed Leary and Roberts (2010) confirm that less than 20 percent of firms adhere to the pecking orders prediction for debt and equity patterns. This is quite understandable as from a simplistic point of view the pecking order theory encourages the use of debt, but simultaneously it is stated that businesses 
are more likely to become profitable if they use less debt. Neville and Lucey (2017) investigating high-tech SMEs discover that a solid, positive association between internal finance and firm age exists, but a strong negative relationship is apparent between the use of debt and age. This is an interesting finding given previous analysis whereby internal finance alone cannot support business investments (Westhead and Storey (1997)). Subsequently, given that high-tech firms are amongst some of the largest in the world, yet SMEs may only have access to internal finance, this could stifle their future growth opportunities. Subsequently, further discussion and analysis amongst the critical areas of the banking and equity sectors will prove fruitful.

Financial integration in traditional banking services has been more reserved in comparison to equity or bond markets (see Degryse and Ongena (2004)). Further scrutiny is therefore needed to understand the drivers behind financial integration, or the lack of it, in banking. Are banks driven by regulatory arbitrage opportunities, by profit motives that derive from pronounced economies of scale, or by risk taking incentives?

Understanding these issues becomes of a paramount importance for the smooth functioning of banking systems of countries with various levels of political, economic, or monetary integration. For example, the recent literature on banking integration in the European Union confirms substantial fragmentation along the national lines. Emter et al. (2017) analyse cross-border banking in Europe after the global financial crisis to find that financial integration in cross-border banking has reversed to some extent after the crisis. They identify non-performing loans as the most important factor that impedes greater integration. Duijm and Schoenmaker (2017) find out that the largest European banks did not fully grab the diversification opportunities. Instead of diversifying into countries with dissimilar economic and financial conditions to obtain the biggest benefit of diversification, banks rather diversify into countries that are similar to their home country.

During the latest global crisis the coexeedances between large banks seems to be particularly strong in the early trading hours due to the influx of overnight information, predominantly from the US. Volatility and to certain extant general market conditions accounted for these coexeedances Lucey and Sevic (2010). Despite fragmentation across national lines, the European banks have diversified their exposures across the global financial system which made them vulnerable to potential shocks stemming from the U.S. subprime mortgage crisis. Abad et al. (2017) confirm that the European banks have largely exposed themselves towards the non-EU entities, partic- 
ularly, shadow banking entities domiciled in the U.S. Further analysis of the benefits and dangers of integration in banking and the impact on stability in the banking systems is therefore needed.

In the aftermath of the global financial crisis, large, complex financial institutions pose a great threat to the global financial system (Saunders et al. (2009)). Although these institutions facilitate international financial integration, such global banks, due to the complexity of their operations, require appropriate regulatory control across borders to prevent the transnational financial contagion risk. The Basel Committee on Banking Supervision (2013b) has identified five important categories to define global systemically important financial institutions, which could be used to obtain a score for each bank. Appropriate additional regulatory measures can then be developed to address the issue of negative externalities from, and the spillover risks of these significant institutions. The score methodology is based on crossjurisdictional activities, size, interconnectedness, substitutability/financial infrastructure, and complexity. From the indicators of each category, one can assess the systemic importance of global systemically important financial institutions and further investigate their spillover risks should they fail.

\subsection{Equity Markets}

Myers (1984) proposes that companies are inclined towards using internal finance over external sources whenever possible. This is because internal finance is more stable and easier to control. It also has lower transaction costs compared to the external sources, particularly equity. Cotei and Farhat (2009) declare that equity is seen as a final option and will only be used when a company does not have any retained earnings or debt opportunities. When analysing high-tech SMEs, it was discovered that previous start-up experience has a key influence in the support and use of equity finance amongst these firms (Neville and Lucey (2017)). The result of this analysis allows for a deeper understanding of previous research whereby high quality, better firms tended to utilise equity finance when the entrepreneurs possessed previous experience (Garmaise (2000)). Increasing financial market interconnectedness has been found to be consistent with increasing equity market integration (see for example Erb and Viskanta (1996), Forbes and Rigobon (2002), Hardouvelis et al. (2006), or Kearney and Poti (2006)), and is seen to be driven by markets forces, such as increasing international trade, increasing business cycle synchronisation, low and convergent inflation and interest rates etc., but constrained by regulatory barriers Aggarwal and Muckley 
(2010). Similar to the correlation between financial markets, international equity market integration varies over time and amongst markets. It is a dynamic process which is often considered in literature within the context of increasing financial liberalisation, globalisation and economic development. According to the generic definition, as stated in Lagoarde-Segot and Lucey (2006), the integration of financial markets means that "all potential market participants with the same characteristics (i) face a single set of rules when they decide to deal with financial instruments, (ii) have equal access to these financial instruments, and (iii) are treated equally when they are active in the market" (Baele et al. (2004)).

More specifically, increased financial market integration manifests itself in the absence of arbitrage opportunities amongst markets situated in different geographical regions. Therefore, integration of financial markets leads to an intensification of equity market interconnectedness at both intra-regional, and inter-regional levels.

The investigation of the information transmission mechanisms, including responses to the common macroeconomic shocks of the financial markets, as well as transmission of shocks occurring on one of the markets compared to other markets, are used as direct measures of integration. In Coelho et al. (2007) the direct approach is considered to be preferable amongst researchers, despite the complexity in finding reliable data and a method to prove the existence of integration. One of the methods used, for example, by Coelho et al. (2007) is a rolling and recursive minimum spanning tree (MST) to assess the evolution of integration amongst 53 equity markets for the period from 1997 to 2006. The MST methodology provides useful visualisation of the interconnectedness between a large set of markets, that can be also applied dynamically to capture the evolution in patterns of stock market linkages over time. The results obtained by ? show that developed European countries have consistently constituted the most tightly linked markets amongst the countries in the sample.

Birg and Lucey (2006) employ the methodology proposed by Akdogan (1996), Akdogan (1997) and its further augmentation by Barari (2004), to measure global equity market integration based on the international risk decomposition model, where integration scores are calculated as a fraction of systematic risk in total country risk vis-à-vis the global benchmark. This measures the contribution of a particular market to global risk. Integration scores calculation involves the use of a countrys beta against the global benchmark portfolio (Birg and Lucey (2006)). The findings demonstrate that 
developing European markets (i.e. Estonia, Hungary, the Czech Republic, Lithuania, and Poland) have become more integrated with both regional and global equity markets. The comparative examination of regional and world integration measures suggested by this methodology is highly important. Although a market can become less integrated with the world, its significance in a region may increase, consequently increasing the degree of regional integration, especially in the light of the formation of regional economic and political alliances (Birg and Lucey (2006)).

True price discovery may be hampered by investor behaviour. Investors continue to display a reluctance to invest in either geographic or culturally distant countries. Although similar benefits to overseas investments can be achieved via investment in internationalised firms (see Farooqi et al. (2015), Fillat et al. (2015) and Krapl (2015)), investors do not seem to recognise these benefits. Investors could invest more heavily in internationalised firms as a hedge for domestic exposure, especially in times of declining domestic markets. However, the opposite has been found to be the case, US investors prefer domestic firms to internationalised firms in declining markets, whether before or after the 2008 credit crisis, while accounting for size, risk and growth effects. In declining markets, domestic firms outperform internationalised firms by more than any under performance in advancing markets (Berrill et al. (2017)).

Kearney and Lucey (2004) highlight a challenge in measuring integration, namely in identifying assets that are comparable in terms of risk. However cultural differences across nations present particular challenges to establishing this, and has yet not been sufficiently addressed. Risk profiles are a reflection of the difficulty of resolving asymmetric information (Hart (2001)) However the relationship between levels of asymmetric information and levels of perceived risk are conditioned by cross-national differences in social trust (Fukuyama (1995)). In order to have a comparison of assets across nations there needs to be a calibration of both social trust and levels of governance. Further, levels of both social trust and national governance are shaped by differences in national culture (Goodell (2017), Gogolin et al. (2017)). Therefore culture will have an impact on transaction costs. As it is difficult to compare assets across markets that are not institutionally integrated, cultural differences establish subtle but meaningful barriers to institutional integration.

Furthermore, similarities as well as differences become visible when examining the financial integration through the lens of the IPO markets. Similar variability in number and volume of IPO filings are prevalent for the USA, 
the UK and Germany since 2001. Especially, crises such as the burst of the dot.com bubble or the latest global financial crisis, seem to affect the numbers of IPO filings and IPO withdrawals in these developed equity markets in a similar manner (Helbing and Lucey, 2017).

In particular, the determinants of IPO success and withdrawal are of special interest to consider financial integration of equity market interconnectedness at both intra-regional and inter-regional level. The recent working paper by Helbing and Lucey (2017) identifies determinants of IPO withdrawal in the United Kingdom and Germany from 2001 to 2015 and finds similarities to previous US based studies as well as marked contrasts. For instance, while Dunbar and Foerster (2008) find that underwriter reputation as well as Venture Capital involvement is key to a successful listing of an IPO, Helbing and Lucey (2017) cannot confirm the hypothesised positive signalling effect for the two largest and most developed equity markets in Europe. They argue that the specific nature of the universal operations of banks in Germany in particular combined with the immaturity of the risk capital markets in Europe are in stark contrast to the financial structures in the USA. However, US findings are not unanimous regarding the effect of Venture Capital involvement. While Busaba et al. (2001) find that backed companies are less likely to succeed their IPO after withdrawing, Dunbar and Foerster (2008) identify Venture Capital involvement as key for a successful return to the equity market. Considering the time period of the sample, this might support the time-varying argument of financial integration on a national level.

Also, Helbing and Lucey (2017) find that better Corporate Governance prior to an IPO decreases the probability of its withdrawal which supports the US findings of Boeh and Southam (2011). Though, each country seems to place its emphasis on individual Corporate Governance metrics, overall the results argue in favour of financial integration in terms of Corporate Governance and IPO markets. The analysis of Helbing and Lucey (2017) also shows pronounced similarities in the determinants of IPO withdrawal for the UK and Germany which enforces the argument that developed European countries are most tightly linked (?). Further studies on financial integration of IPO markets which examine underpricing in European countries include Goergen et al. (2009) or Engelen and van Essen (2010).

The knowledge about interconnectedness of equity markets can be also very helpful for stock market investors in construction of their trading strategies that exploit the information not only from the domestic market, where the trades are executed, but also from other foreign markets which spill over 
volatility and transmit returns to other markets, which are aligned next in the particular geographical markets sequence. There exists evidence that inclusion of the information from the foreign markets, which is measured by models which capture interdependence and interconnectedness effects, substantially improves performance of such investment strategies (see for example Ibrahim and Brzeszczynski (2014)).

Equity market integration is the process of unification of the markets. Integrated financial markets have unified risk-adjusted returns. Equity markets around the world have experienced increased integration in recent decades influenced by globalization and advances in informational technology (Rosati et al. (2017)). The global financial crises in the 1990s, and especially during the 2000s, accelerated the process of integration amongst the equity markets. The integration process started among the developed countries. After the worlds major equity markets became integrated to a large extent, emerging markets started the removal of restrictions and therefore boosted their process of integration with the developed markets; a recent example for China and Hong Kong can be found in Wu et al. (2017).

Equity markets integration brings many benefits to countries but also some risks. The major risk of integration is the possibility of contagion: a subject widely studied during the 1990s and 2000s global financial crises. Contagion problems during the recent financial crises caused many researchers to question the claimed benefits of global financial integration, and to decide that it ultimately can bring global financial instability. The threat of systematic instability is present in the case of global and regional integration as complications from one market are easily transferred to another.

One prominent factor influencing stock returns as well as regional and global interconnectedness of equity markets is political uncertainty. Recent events like the Arab Spring in the Middle East \& North Africa (MENA) region, civil war in Libya, and riots in Egypt and Tunisia during 2011, the political and military crisis in Thailand during 2006, and the turmoil in the Ukraine starting in 2014 are important for international investors due to their huge impact on stock market performance in emerging countries. However, there is only very limited empirical research testing the impact of political risk on equity markets (Lehkonen and Heimonen (2015)).

Current literature documents that political risk is an important factor in explaining stock returns and therefore impacts the interconnectedness of equity markets in terms of volatility spillovers and return transmission. A standard risk-return relationship suggests that investors demand a higher 
return for taking higher risks. Following that rationale, political risk should be priced together with other risks and therefore should negatively impact excess stock returns, which is confirmed in studies from Erb et al. (1996) and Bilson et al. (2002). However, political risk is often found to violate the classic risk-return relationship, leading to the so-called political risk sign paradox, exemplified in situations like a reduction in political risk being associated with higher stock returns (Diamonte et al. (1996); Perotti and van Oijen (2001); Lehkonen and Heimonen (2015)).

Diamonte et al. (1996) further argue that political stability and upgrades to a political risk profile lead to higher returns in an emerging market setting. Erb et al. (1996) and Bilson et al. (2002) find that political risk has a greater impact on returns in emerging markets than in developed markets. However, Diamonte et al. (1996) emphasise the concept of global political risk convergence, indicating that the differential impact of political risk on returns in emerging and developed markets narrows over time. Moreover, Dimic et al. (2015) argue that the composite political risk is negatively associated with equity market returns, implying that higher (political) risk is associated with lower stock market returns. For each of the components of political risk, the effect across developed, emerging, and frontier markets can be different. Thus further research is warranted in order to fully understand the impact of political risk on equity returns and the interconnectedness between emerging and developed equity markets.

\subsection{Government Bond Markets}

The financial integration of government bond markets is an important topic in international finance, since it has important implications for monetary policy-making independence and bond portfolio diversification (see Yang (2005)). Despite having relevant practical implications, the topic of bond markets' financial integration has received less attention in the literature than equity market integration. Most of the literature on government bond markets integration has been traditionally focused on developed markets, especially in Eurozone and G7 economies (see for example Abad et al. (2010), Abad et al. (2014), Christiansen (2014), Kumar and Okimoto (2011), and Pozzi and Wolswijk (2012)).

For instance, Pozzi and Wolswijk (2012) examine the integration dynamics of Euro area government bond markets. Their main finding is that the markets were almost fully integrated before the beginning of the 2007-2009 financial crisis, but that during the crisis the degree of integration decreased. 
This is supported by Arghyrou and Kontonikas (2012) who find that prior to 2007, European sovereign bond markets mainly operated on convergence trades, but were mainly driven by macroeconomic factors and international risk after the crisis. Kumar and Okimoto (2011) use a sample of the largest G7 economies (excluding Japan) to examine whether government bond markets of those countries were integrated in the period before the onset of the crisis. In addition, they address the question to what extent the integration at the short and long end of the yield curve differ and find that integration at the long end of the yield curve had been increasing, and that this increase was significantly greater than at the short end. Christiansen (2014) finds that EMU countries exhibit higher level of government bond integration than non-EMU countries. Furthermore, integration is also stronger for old EU members relative to the new EU members. Abad et al. (2010) examine how two sources of systemic risk (world and Eurozone risk) affect bond market integration of EMU and non-EMU members. They find that world risk factors are more affecting government bond returns of non-EMU countries than those of EMU countries. Abad et al. (2014) show that the level of government bond integration for all European countries is time-varying and decreases after the beginning of the global financial crisis in August 2007. More specifically, integration was slowing down as markets moved towards higher segmentation following the onset of the crisis, which highlighted differences of country risk factors across European markets. By analysing EMU and non-EMU countries separately, they also find out that the financial crisis had much more negative effects for EMU members sovereign bond markets in comparison to non-EMU members.

One specific stream of the literature on bond market integration concentrates on emerging and frontier markets as well. For instance, Bunda et al. (2009) use adjusted cross-country correlations to examine how common external and idiosyncratic factors are affecting bond markets co-movement in emerging markets, while Piljak (2013) investigates co-movement dynamics of emerging and frontier government bond markets with the US market and determinants of time-varying co-movements. More recently, Piljak and Swinkels (2017) analyse time-variation in correlation of frontier government bond markets (denominated in US Dollars) with respect to emerging bond markets, the US corporate bond market, and the US Treasury.

Future research on bond market integration could focus on identifying the most relevant determinants affecting government bond integration and examining whether the effect of those factors differ between developed and 
emerging bond markets. Distinction between developed and emerging government bond markets is important in this context, given that emerging markets bonds are often perceived as "equity-like" assets due to high country risk (see Piljak (2013)). This implies that importance of certain determinants of market integration might differ amongst developed and emerging markets. In particular, political risk factors, development of financial system, and sovereign credit ratings might be more significant in affecting emerging bond markets relative to developed bond markets. Another future avenue for research in bond market integration would be development of bond market integration measure, which would be used to measure co-movement dynamics between bond markets internationally. The creation of such a measure is a challenging task, given the complexity of factors, both country-specific and global, that are impacting government bond pricing on the individual country level but also on co-movement at cross-country level.

\subsection{Corporate Bond Markets}

As for the government bond market, financial integration of the corporate bond market is relevant for the transmission of monetary policy impulses and portfolio diversification. In addition, the corporate bond market works as a direct link between the financial and the real side of the economy, being one of the markets where corporations can fund their own activities. However, the empirical literature has mainly focused on the fragmentation in the sovereign debt market, often neglecting the role of the corporate segment.

The few existing contributions, such as De Santis (2016), Horny et al. (2016), Zaghini (2016), and Zaghini (2017), focus on the Euro-area. Indeed, an important consequence of the turmoil in the Euro-area sovereign debt market which started in 2010 was the transmission of the crisis to the corporate bond market. Eventually, not only banks but also firms were involved in the crisis via the transfer risk phenomenon, experiencing a deterioration of their funding abilities (Bedendo and Colla (2015)). The deterioration was unequal across countries and led to an increasing market fragmentation and segmentation along national borders.

Three empirical models to assess changes in financial market integration can be distinguished:

1. Building on the concept of excess bond premium (EBP) by Gilchrist and Zakrajsek (2012), the difference between the duration-adjusted bond credit spread and the spread justified by observable credit risk, 
De Santis (2016) expands the measure to also include market risk and idiosyncratic shocks. Relying on secondary market trades of bonds by non-financial corporations, he proposes the degree of dispersion across countries of domestic EBP values as a likely measure of fragmentation. De Santis (2016) finds that fragmentation (the standard deviation of EBP values) was very large until 2003 (especially for high yield bonds), and declining just before the burst of the global financial crisis, revealing two peaks of almost identical size in the period after the Lehman Brothers default and in the most acute phase of the sovereign debt crisis (between 2011 and 2012). Having significantly declined after the announce of the Outright Monetary Transactions (OMT) in July 2012, fragmentation increased again at the beginning of 2015.

2. In order to assess the degree of market fragmentation, Horny et al. (2016) instead focus on country-specific dummies. In particular, their econometric approach is based on dummy regressions for three main variables:

- the countries' fixed effect

- the bonds rating

- the slope of the term structure

By looking at the secondary market price of bonds issued by firms head quartered in the top four Euro-area countries, they show that the spread to German bonds is hardly ever different from zero for France, while it peaks for Italy at the end of 2011 and for Spain at the end of 2012. They then rely on the sum of the country (dummy) coefficients to obtain their measure of financial market fragmentation; while fragmentation remained fairly limited in the post Lehman period, it reached very high levels at the heights of the Euro-area sovereign debt crisis in 2011 and 2012. Fragmentation receded gradually after the OMT but was still detected at the beginning of 2015 .

3. Zaghini (2016) argues that the best way to assess fragmentation is by looking at the primary bond market where firms face the true cost of funding. Relying on a model proposed by Sironi (2003) for the Euro-area, he shows that country determinants were indeed relevant for the pricing of corporate bonds over an extended period of time, thus openly breaking the law of one price. By using the sum of the spread to German bonds as the measure of fragmentation, Zaghini (2016) reports that the bond market was characterised by perfect integration 
before 2007 (for each single Euro-area country), financial fragmentation erupted during the global financial crisis, increased to unprecedented levels during the sovereign debt crisis and declined (but not disappeared) after the launch of the OMTs. At the end of 2014, firms from two countries (Italy and Portugal) were still experiencing a cost of funding which was above that implied by fundamentals. Zaghini (2017) not only shows that fragmentation completely disappeared in the period following the announcement of the European Central Banks quantitative easing in January 2015, but also reports that banks are generally not different from other companies when funding themselves on the primary market; indeed, they have born the same market distortions as non-financial corporations.

All the above-mentioned studies suggest that the non-conventional monetary policy measures deployed by the ECB were successful in reducing and even erasing corporate bond market distortions. An interesting further research avenue might want to investigate the effects of the most recent ECB programme of asset purchases (CSPP), which contemplates the direct buying of corporate bonds on both primary and secondary markets. In particular, it might be useful to assess whether the role of a big player such as the ECB playing in the market is not introducing distortions in prices or volumes (for instance, by influencing just a market segment or discouraging bond placing by non-eligible issuers), and whether a rebalancing channel akin to that of the sovereign bond market is also at work in the corporate bonds market.

\subsection{Equity Markets Integration}

The level of integration of equity markets worldwide plays a key role for the transmission of the benefits of global portfolio diversification and hence, the extent to which firms are required to invest internationally to exploit such benefits. As a result, the cross-border market for corporate control offers a direct channel towards this principle, which ultimately offers some desirable portfolio diversification benefits. In particular, the cross-border market for corporate control has grown rapidly in recent years exceeding 526 billion US Dollars in 2011 from only 99 billion US Dollars in 1990 (United Nations (2012)).

A key issue is the impact of such growth on the costs and benefits of firms engaged in cross-border mergers and acquisitions (CBA), which is directly related to the main incentives of firms engaged in CBAs. A rich array 
of studies in the financial economics literature shows that CBAs are largely wealth-increasing for the shareholders of the target firms, but they are mostly wealth-destroying, or at best wealth-neutral, for the shareholders of the acquiring firm. Therefore it is unsurprising that a number of papers in various disciplines have examined the price paid by acquirers, usually referred to as the takeover premium, in other words, a higher purchase consideration compared to the current market value. Excessive takeover premiums are often considered as one of the reasons for the decline in acquirers' value around CBA announcements (Moeller et al. (2005)). Put forward, extant literature suggests that the takeover premium in CBAs is influenced by a diverse range of factors including:

- Managerial motivations, such as managers' enhanced job security (Amihud and Lev (1981)).

- National pride of acquiring targets based in developed countries (Hope et al. (2011)).

- Acquiring the target firms' characteristics, such as market access (Doukas and Travlos (1988)), industry affiliation (Denis et al. (2002)), accounting quality (Bris and Cabolis (2008)), intangibility of assets (Chari et al. (2010)), and international taxation (Huizinga et al. (2012)).

- Other deal-specific features (Eckbo (2009)).

It could also be argued that in a perfect capital market investors can achieve the gains of global portfolio diversification by investing on the shares of foreign firms and hence there is no need for firms to engage in CBAs. However, owing to country specific financial regulations investors based in certain countries might not have opportunities to invest in foreign financial instruments due to the frictions created by the regulations. Hence, portfolio investors' ability to diversify internationally is bounded. For instance, investors based in countries that have managed exchange rate systems are not allowed to buy foreign currencies to invest in shares that are traded in foreign markets. On the other hand, firms might not face such severe restrictions and be allowed to acquire foreign firms or shares in a foreign market. Consequently, investors investing on the shares of domestic firms that have foreign subsidiaries can mimic the benefit of international portfolio diversification. Therefore, global diversification by firms can help investors to exploit 
the benefit of international diversification where portfolio diversification or cross-country arbitrage at individual investors level is not feasible due to regulatory restrictions in capital mobility.

Overall, previous studies suggest that while CBAs are associated with higher takeover premiums than domestic deals, we are far from fully understanding the main sources of such takeover premiums. These studies have been focused on a wide range of factors including firm, deal, and country specific ones. An interesting research avenue that might offer meaningful insights regarding the distribution of the takeover premium offered in CBAs is to further explore the impact of regulatory restrictions in capital mobility.

\subsection{Commodity Markets}

Since the classical work by Working (1949) and Brennan (1958) on the theory of storage, commodities have been extensively studied over the years. In particular, Pindyck and Rotemberg (1990)'s pioneering study set the foundation for the concept of co-movement: the persistence of the prices of largely unrelated commodities to move together. This concept was later extended by Cashin et al. (1999), who introduced a measure of so-called concordance: the proportion of time that the prices of two commodities are simultaneously in the same slump or boom period. More recent examples of this literature are Ai et al. (2006), Lescaroux (2009), Natanelov et al. (2011), De Nicola et al. (2014), and Fernandez (2015a), amongst many others.

Irwin and Sanders (2011) detail how commodity investment flows have increased from 15 billion US Dollars in 2003 to 250 billion US Dollars in 2009. This increase in volume is attributed to the financialisation of futures markets that began in the early 2000s (Gogolin and Kearney (2016)). Cheng and Xiong (2014) state that since the financialisation, commodity futures now represent an additional asset class that sits alongside stocks and bonds. The entrance of this new cohort of investors, however, significantly changed how commodities interact with other assets (Adams and Glück, 2015). More precisely, as commodities began to command a greater proportion of market participants' portfolios, they were traded in a manner similar to equities. This is in contrast to earlier conclusions of commodity prices being only weakly correlated with equity markets (Bessembinder and Chan, 1992).

Over the years new statistical techniques have been devised to gauge co-movement amongst a set of financial assets. For instance, Kenett et al. (2015) developed the concept of influence: the average partial correlation of one asset with respect to others. Based on price information for the period 
of January 1968 to December 2013, Fernandez (2015b) found that there was strong co-movement amongst the average influences of nominal returns of industrial and precious metals since 2003. On the other hand, and as expected, average influence amongst unrelated commodity returns was found to be generally negligible, except for the period of financial turmoil of 20072010. New techniques to measure co-movement also include network theory. See, for instance, the recent article by Diebold et al. (2017) which finds that commodity clustering generally matches industry grouping, while energy, industrial metals, and precious metals are firmly connected.

On the other hand, it appears that in recent years a new strand of literature is under way: resources finance. That is, a bridge between the finance and renewable/non-renewable resources literature. Here the examples are numerous, particularly in regards to strategic metals (rare-earth elements such as indium, iridium, rhodium) and precious metals. Recent contributions include Batten et al. (2010), Aruga and Managi (2011), Mancheri and Marukawa (2016), O'Connor et al. (2015), Lucey et al. (2016), Ge et al. (2016), and Lau et al. (2017) - see also the special issue on white metals in this journal. Indeed, in that spirit, a change in the nature of white precious metals can be observed, shifting from commodities to investment assets (Vigne et al. (2017)). An interesting question is to understand whether this reflects an actual need for more diversification assets, or whether this is a mere reflection of a growing finance industry that turns commodities into new products to be placed to investors. In any case, the macroeconomic determinants of white precious metal prices are changing and so should the views of researchers.

\subsection{Risk Management}

Major types of risk corporations might be exposed to include commodity price risk, interest rate risk, and/or foreign exchange risk. For example direct and indirect foreign exchange rate exposure occurs when firm value is impacted by fluctuations in foreign exchange rates. Hutson and Stevenson (2010) and Aggarwal and Harper (2010) suggest that the globalisation of product markets has heightened indirect relative to direct foreign exposure. Bartram et al. (2010) suggest that foreign exchange rate exposure can be mitigated via financial and operational hedging techniques. Hutson and Laing (2014) examine 953 US multinational firms and report strong evidence that operational and financial hedging mitigates foreign exchange rate exposure. Examining the GFC period, they find that the effectiveness of financial 
hedging diminishes and suggest that operational hedging could potentially provide stronger protection than financial hedging during times of heighten exchange rate volatility. Laing et al. (2017) examine the US oil and gas industry and find significant exposure to commodity price risk. They report no evidence that operational hedging is effective; rather that financial hedging is significant and impactful in reducing commodity price exposure. Consistent with Hutson and Laing (2014), they find that the effectiveness of financial hedging diminishes during times of stress. Asness et al. (2009) claim that in 2008 it was rather difficult to apply a financial hedging strategy in the convertible bond markets due to the lack of liquidity. Any claim for redemption forced market agents to sell convertible bonds and increase the "cheapness" of the financial asset. Accordingly, even potentially profitable strategies had to be abandoned due to short squeeze and the necessity to close both long and short positions. An interesting future research question is to understand how firms operating in integrated global financial markets can successfully mitigate risk during periods of high volatility.

\subsection{FinTech}

Over the last decade, technology advancement has transformed the financial services industry at an accelerated pace. From digital currencies to the use of Blockchain in financial transactions, the financial world is innovating at a rapid pace. However, without regulation and understanding of the technology and its impact to the sector, FinTech could do more harm than good. There have been a number of recent papers that have studied Bitcoin from an economics and financial perspective. For instance, Cheah and Fry (2015) argue that if Bitcoin were a true unit of account, or a form of store of value, it would not display such volatility expressed by bubbles and crashes. Dwyer (2014) finds that the average monthly volatility of Bitcoin is higher than that for gold or a set of foreign currencies, and the lowest monthly volatilities for Bitcoin are less than the highest monthly volatility for gold and currencies. Brire et al. (2015) show that Bitcoin offers significant diversification benefits for investors while Dyhrberg (2016) shows that Bitcoin has similar hedging capabilities as gold and the dollar, and as such can be employed for risk management. Fry and Cheah (2016) develop an econophyscis model to reveal that Bitcoin and Ripple (another cryptocurrency) are characterised by negative bubbles while Urquhart (2016) shows that the Bitcoin market is inefficient. Sas and Khairuddin (2017) highlight that the lack of regulation in Bitcoin's crytocurrency blockchain technology 
leave users open to hacking, fraud and theft. However given the increased attention, usage, and importance to investors, the analysis of FinTech is very much limited.

Therefore there needs to be a growing literature on FinTech and its impact on the financial sector. Possible topics include big data analytics, social media analytics, textual sentiment analysis, agent based models and simulation, Blockchain and distributed ledger technologies, disintermediation of long established institutions such as banks, high frequency trading strategies, machine learning, cryptocurrencies, digital wallets, peer-to-peer payments, financial transactions in the Internet-of-Things, asset allocation and risk management as well as crowdfunding. While recent studies about the implications of digital finance for individual economies exist, such as Litvack and Vigne (2017) for India, all of the above topics outline a few areas that academic research could pursue in this rapidly advancing field.

\subsection{Alternative Investments}

Another promising area for future research toward financial integration is the area of alternative investments, such as hedge funds for example, and the impact that they can have on the stability of the system. Currently, hedge funds are not regulated by the be Securities and Exchange Commission (SEC). They are of private nature with all the characteristics derived from it Lhabitant (2004). As the general public has no access to this pool, regulators don't regard this pool as a traditional investment vehicle such as mutual funds, portfolio stocks, bonds or cash, so there is no need to regulate them nor any need for disclosure. Hedge fund managers are not obliged to disclose their underlying investment practices and there is no obligation to conform to the requirements of registered investment companies. In addition, management may pursue a wide range of financial instruments and any type of investment strategy even if this includes short selling, derivatives, leverage, real-estate, non-listed or illiquid securities. In the coming years there is going to be a pressure for more transparency and regulation towards hedge funds. This is therefore a good opportunity to examine how these potential changes can have an impact on how the funds operate in relation to the market operation as well.

More specifically, an emerging area of interest is the risk capital market with Venture Capital and Private Equity firms on an intra- and inter-regional level. Groh et al. (2010) elaborate specific attractiveness indices for Venture Capital and Private Equity investments on a country-specific level. Despite 
integrating markets in Europe, differences in the risk capital markets remain severely pronounced, in particular for the largest economies (Tykvova and Walz (2007)).

\subsection{Bank liquidity}

The 2007-2009 financial crisis that caused not only the collapse of the financial system but also huge negative externalities to the entire economy has highlighted the liquidity management problems faced by banks. When banks fund more long-term illiquid assets with less short-term debt, they are more likely to become unable to roll-over their borrowing during the financial crisis (see Brunnermeier (2009), Diamond and Rajan (2009), Afonso et al. (2011), and Acharya and Merrouche (2013)).

In the wake of the subprime crisis, banking regulations have been rewritten all over the world with the aim of gaining public trust and enhance banking stability. The Basel Committee on Banking Supervision (Basel Committee on Banking Supervision (2013a)) introduced a quantity-based liquidity standard, named Basel III, to strengthen bank liquidity risk management practices. This represents a starting point to quantify individual banks market-implied vulnerability to system-wide funding constraints during periods of stress. Acknowledging how the new liquidity standard influences the financial sector is important in the Basel III reform process. The topic on bank liquidity is raised at a time of significant Basel III reforms, and could therefore propose significant contributions for future regulatory implications before its first implementation over the next few years.

Studying banks in the Euro area, Aldasoro et al. (2017) find that increasing liquidity requirement could reduce systemic risk more than higher equity requirements could, supporting the new regulatory framework of Basel III. Fecht et al. (2012)'s analysis indicates that financial integration could induce banks to specialise in their lending through pooling liquidity risks in the interbank market. Although the benefit of risk sharing exists, banks reliance on the interbank market liquidity provision could rise, hence, leading to greater contagion risk. Luo et al. (2016) is a recent study examining the impact of financial openness on bank risk and efficiency. Considering commercial banks in 140 countries, Luo et al. (2016) report a direct negative effect of financial openness on profit efficiency. Bank risk is found to increase as a result of financial openness, however, indirectly through lower profit efficiency. Liquidity is yet to be controlled for in their analysis. It could be interesting to take into account liquidity risk/interbank market liquidity provision and 
systemically important financial institutions (identified by Basel indicators) when investigating the interplay between financial integration, bank risk, and bank efficiency. In this case, micro-evidence can be reported at the bank-level for policy makers to accommodate applicable supervisory schemes.

\subsection{Derivatives Markets}

Merton and Bodie (1995) identify six core functions performed by the financial system to facilitate the allocation and deployment of economic resources:

1. To provide ways of clearing and settling payments to facilitate trade.

2. To provide a mechanism for the pooling of resources.

3. To provide ways to transfer economic resources across time and space.

4. To provide ways of managing risk.

5. To provide price information.

6. To provide ways of dealing with incentive problems.

Haiss and Sammer (2010) distil these functions into three derivativespecific channels, through which derivatives influence the integration of financial markets and economic development. Namely, the volume channel, the efficiency channel and the risk channel.

The volume channel facilitates and increases the accumulation of capital - derivatives markets have become very successful in pooling enormous amounts of capital. Figure 1 illustrates daily dollar volume of options on the SPX split into call and put volumes.

The efficiency channel enables efficient substitution of cash market trades, transferring resources across time and space. Currency and interest rate swap derivatives allow borrowers and investors to allocate or obtain capital efficiently to and from the cheapest/most efficient foreign markets.

The final channel, the risk channel, enables investors to cap their exposure to risky trades, enabling agents such as pension fund managers with risk averse clients to increase potential yields while capping losses through the purchase of put options. The importance of tail risk in the cost of providing this type of insurance is emphasised in Bakshi and Madan (2006) and McGee and McGroarty (2017), who link it to the well-researched variance risk premium in options markets. Evidence of the important risk management role of options markets can be seen in Figure 2 that illustrates the dollar volume of gold ETF options split into put and call volumes. The ratio 


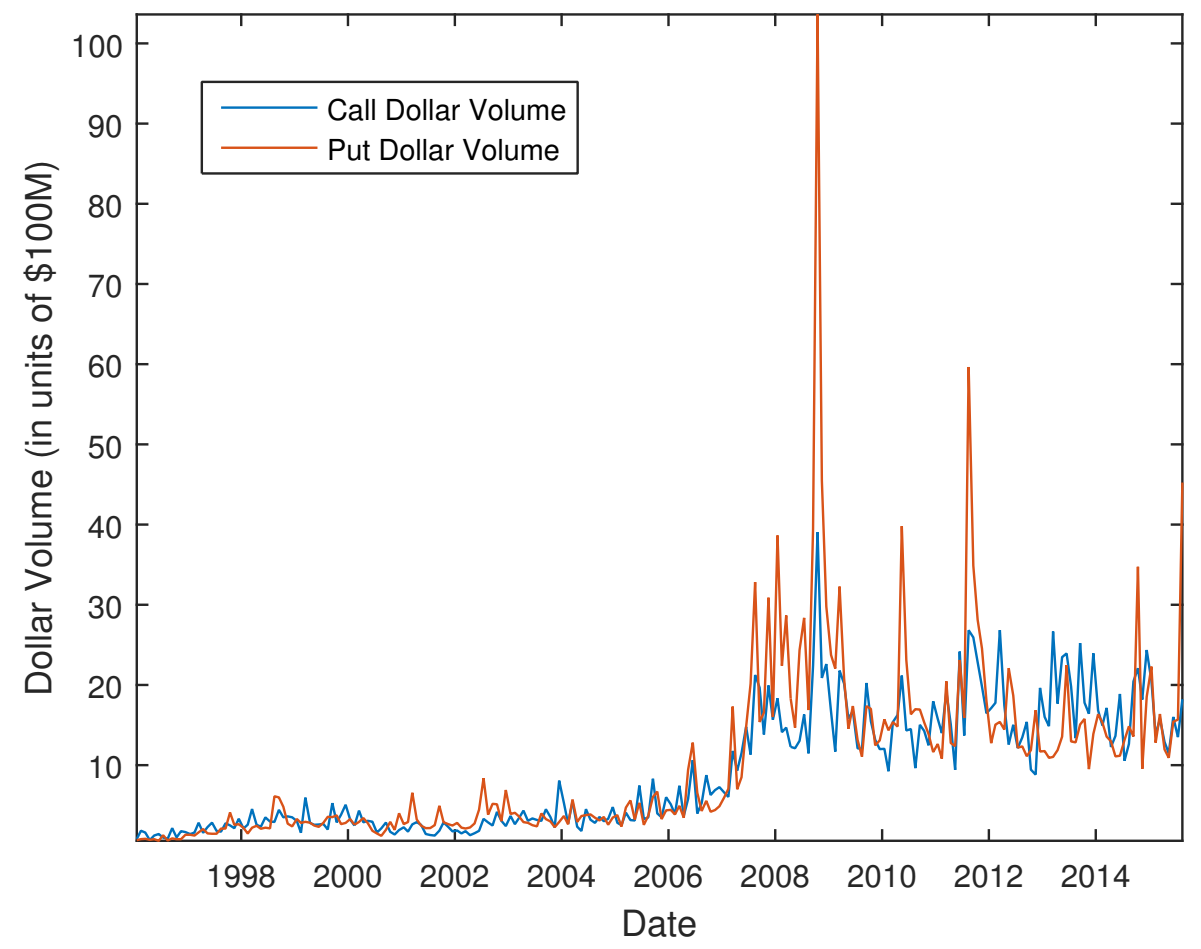

Figure 1: SPX option monthly dollar volume split into call and put volumes covering options with all expiries traded in a given month (source: Option Metrics). 


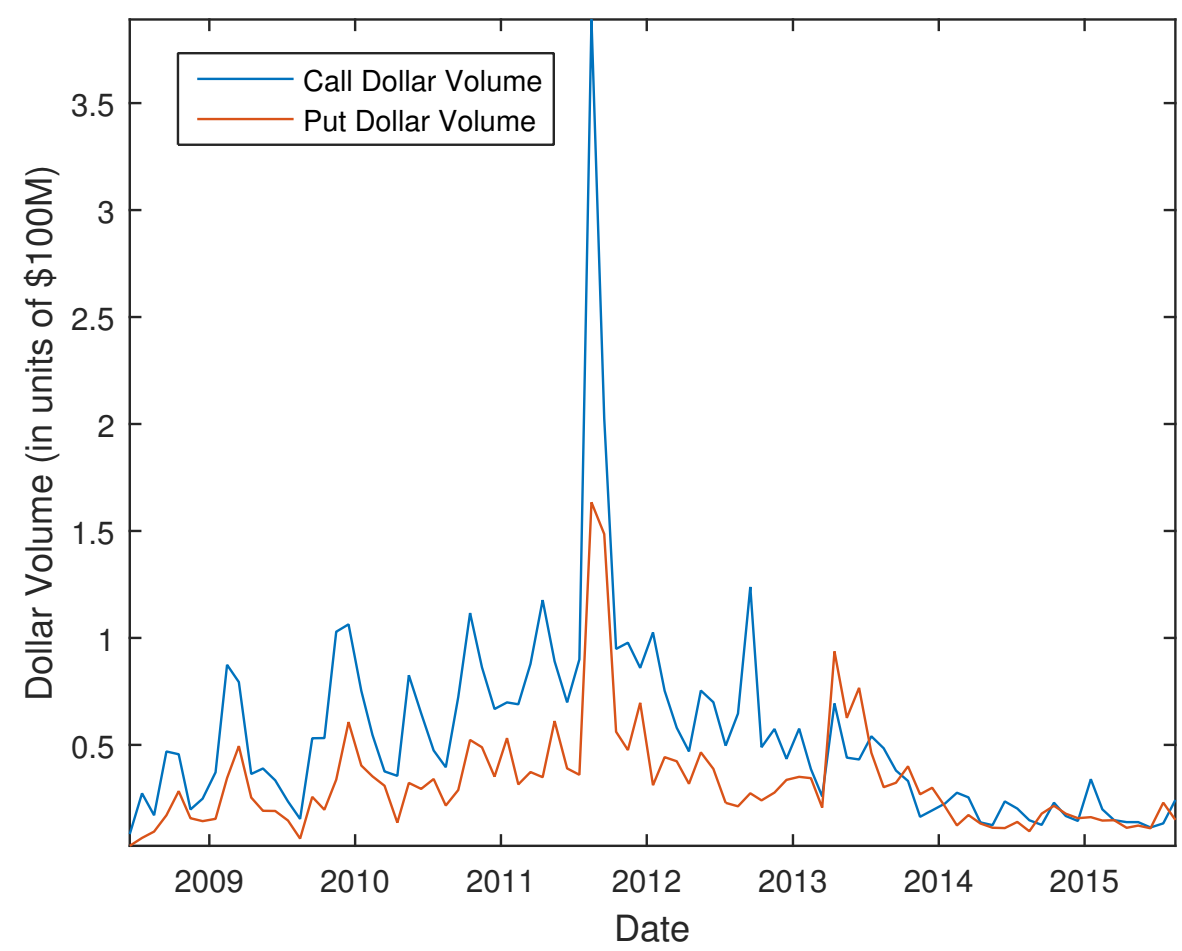

Figure 2: GLD ETF option monthly dollar volume split into call and put volumes covering options with all expiries traded in a given month (source: Option Metrics). GLD options started trading on the CBOE in June 2008.

of calls to puts is approximately 2:1 (compared to approximately 1:1 for the SPX in Figure 1). This highlights the asymmetrical importance of gold as a safe haven, as a call option on gold is equivalent to a put option on the equity market in periods when the two are negatively correlated.

While the potential benefits of liquid derivatives markets are uncontentious there is a question as to whether these come at too high a price, as the complexity and high leverage available in the products also increases risk exposure and leverages potential losses. This has led a number of researchers to question whether financial derivatives were to blame for the global financial crisis in 2008 (see e.g. Duffie (2008), Murphy (2009) and Greenberg (2010)).

The ongoing challenge in derivatives markets is in how to continue to encourage innovations that benefit the financial system while carefully regu- 
lating to mitigate the impact of leverage on systemic risk. The high leverage available in derivatives markets can incentivise risk-taking in institutional traders with an asymmetrical payoff function (who share in trading profits but do not contribute to losses). Recent regulatory changes in 2014 in the EU attempt to address this through limits on trading bonuses however, as noted by Murphy (2013), regulatory intervention can have unintended negative consequences, potentially even increasing the risks it was introduced to avoid.

Related with the OTC credit derivatives market, the CDS (Credit Default Swaps) has attracted considerable attention specially since 2008. CDS spreads are considered a good proxy for credit risk and default probabilities. CDSs are also the most liquid credit derivative products and account for about half the amount of credit derivatives traded on the derivatives market. During the last years, the vulnerability of European markets has become evident, affecting the real estate sector and causing a rapid deterioration in major European economies, and to a greater extent in the distressed peripheral economies inside the Eurozone. As a consequence, a recent strand of the literature analyses the channels of European credit risk transmission in credit markets before and during this turbulent period. Understanding how transmission works among financial institutions and/or sovereigns is key to understanding the propagation of financial crises. Moreover, an understanding of the dynamics of international risk transmission is key to regulators and policy makers who need put in place a framework for the prevention of contagion in financial markets.

Overall, the existing CDS literature has explored the connections between the CDS market and the bond and/or stock markets (see Blanco et al. (2005), Forte and Peña (2009), or Delatte et al. (2012), Guo et al. (2011), amongst others). More recent articles have identified a number of contagious relationships in the sovereign credit risk markets. Using CDS spread changes, Caporin et al. (2013) show that the propagation of shocks in the major Euro area countries has been remarkably constant during 2008 to 2011 even though, in a significant part of the sample, periphery countries have been greatly affected by their sovereign debt and fiscal situations. Using the Granger-causality test Kalbaska and Gatkowski (2012) conclude that sovereign risk is mainly concentrated in EU countries, while Ballester Miquel et al. (2014) show evidence of a significant change in credit risk transmission with the outbreak of the global financial crisis. The effect is striking from eurozone banks to non-eurozone banks. 
Another strand of the literature focuses on the contagious relationships between the sovereign and bank CDS markets (Alter and Schüler (2012), Dieckmann and Plank (2012)). Some studies focus on credit risk volatility transmission. Groba et al. (2013) test the existence of cross-border volatility effects between the central and the peripheral European Union (EU) countries. They show a significant volatility spillover from distressed to central Eurozone economies leading to a significant impact on the default swap risk premia. Using an asymmetric multivariate BEKK model, Alemany et al. (2015) show that the global financial crisis that originated outside Europe is characterised by unidirectional volatility spillovers in credit risk from inside to outside the Eurozone. By contrast, the Eurozone debt crisis is revealed to be local in nature with the Euro as the key element, suggesting a financial market fragmentation within the Eurozone between distressed peripheral and non-distressed core Eurozone countries, whereas retaining the local currency has acted as a firewall.

\subsection{Financial market wide dependences}

International financial markets are a network, which are influenced by the macro economy, policy decisions, and institutional factors. An important element in future research regarding financial market connectedness and therefore the depth of integration - is not only the connectedness within one asset class (e.g. equity markets) or between two asset classes (e.g. equities and bonds), but the simultaneous connectedness between a wide variety of asset markets: equities, bonds, FX, commodities, bonds, housing markets etc., within a country and across countries. By understanding the time-varying relationship between the different asset classes, and how the changing dependence structure between two markets affect the other markets, we can better understand financial market interconnectedness. Steps in this direction are taken by Diebold and Yilmaz (2015) (and their related papers), their approach building on network analysis and GVAR models. Since there are many markets and daily (or even higher) frequencies can be used, developing models able to handle large data sets efficiently will be crucial.

Being able to forecast how connectedness changes over time, for example due to the changing economic situation (e.g. business cycles), the policy environment (e.g. accommodating monetary policy), or the institutional framework, will also be important, as is finding the common factors driving connectedness between different asset classes. This would improve our ability to forecast financial markets and economic developments in general, and 
be useful for risk management purposes. For example, Minoiu et al. (2014) use network analysis to find that financial connectedness can be useful in predicting banking crises ${ }^{1}$. Using connectedness measures as an early warning indicator of crisis is of course an important application of system-wide connectedness.

Using GVAR approach to evaluate contagion between the US and European CDS banking market, Ballester et al. (2016) shows evidence of both systematic and idiosyncratic contagion. Whereas systematic contagion was the main factor during the global financial crisis of 2008, the idiosyncratic component became more relevant during the subsequent eurozone debt crisis. Furthermore, the methodology allows them to identify the transmitters and receivers of contagion. They conclude that US banks were the transmitters of systematic contagion in the context of the global financial crisis, with EU banks being net receivers. By contrast, during the eurozone crisis, banks in euro-peripheral countries transmit the idiosyncratic contagion, banks in euro-core countries transmit the systematic one, whereas, US banks did not receive instability from eurozone banks.

\section{Conclusion}

The advancements made in the field of finance have uncovered multiple research questions that still need to be addressed. This paper proposes many future research questions and highlights the relevance of the research proposed.

Being the results of a crowdsourcing experiment that consisted of asking international experts in the field of financial research to contribute to an overview of the current state of knowledge in their field, this paper will be valuable to fellow researchers and practitioners who can use it as a source of inspiration for their own work.

It is one of the first studies of it's kind to unite researchers from different fields and publish their ambitions for future research, and their conception of important research questions to address.

\footnotetext{
${ }^{1}$ The Introduction in Minoiu et al. (2014) gives a good overview of the current literature on the relationship between business cycles and financial connectedness.
} 


\section{Bibliography}

Abad, J., M. D'Errico, N. Killeen, V. Luz, T. Peltonen, R. Portes, and T. Urbano (2017). Mapping the interconnectedness between EU banks and shadow banking entitiies. Presented at INFINITI 2017.

Abad, P., H. Chuliá, and M. Gómez-Puig (2010). EMU and European government bond market integration. Journal of Banking \& Finance 34(12), $2851-2860$.

Abad, P., H. Chulia, and M. Gomez-Puig (2014). Time-varying integration in european government bond markets. European Financial Management 20(2), 270-290.

Acharya, V. V. and O. Merrouche (2013). Precautionary Hoarding of Liquidity and Interbank Markets: Evidence from the Subprime Crisis. Review of Finance 1\%, 107-160.

Adams, Z. and T. Glück (2015). Financialization in commodity markets: A passing trend or the new normal? Journal of Banking $\&$ Finance 60, 93-111.

Afonso, G., A. Kovner, and A. Schoar (2011). Stressed, Not Frozen: The Federal Funds Market in the Financial Crisis. The Journal of Finance 66(4), 1109-1139.

Aggarwal, R., L. B. and C. Muckley (2003). Dynamics of equity market integration in europe: Evidence of changes over time and with events. Working Paper, Institute for International Integration Studies. Trinity College Dublin.

Aggarwal, R., L. B. M. and C. Muckley (2010). Dynamics of equity market integration in europe: Impact of political economy events. Journal of Common Market Studies 48(3), 641-660.

Aggarwal, R. and J. T. Harper (2010). Foreign exchange exposure of domestic corporations. Journal of International Money and Finance 29(8), 16191636.

Ai, C., A. Chatrath, and F. Song (2006). On the co-movement of commodity price. American Journal of Agricultural Economics 88, 574-588. 
Akdogan, H. (1996). A suggested approach to country selection in international portfolio diversification. Journal of Portfolio Management 23(1), 33-39.

Akdogan, H. (1997). International security selection under segmentation: Theory and application. Journal of Portfolio Management 24(1), 82-92.

Aldasoro, I., D. D. Gatti, and E. Faia (2017). Bank networks: Contagion, systemic risk and prudential policy. Journal of Economic Behavior $\&$ Organization.

Alemany, A., L. Ballester, and A. González-Urteaga (2015). Volatility spillovers in the European bank CDS market. Finance Research Letters 13, $137-147$.

Alter, A. and Y. Schüler (2012). Credit spread interdependencies of european states and banks during the financial crisis. Journal of Banking and Finance 36, 3444-3468.

Amihud, Y. and B. Lev (1981). Risk Reduction as a Managerial Motive for Conglomerate Mergers. The Bell Journal of Economics 12(2), 605-617.

Andersson, M., E. Krylova, and S. Vhmaa (2008). Why does the correlation between stock and bond returns vary over time? Applied Financial Economics 18(2), 139-151.

Arajo, E. (2009). Macroeconomic shocks and the co-movement of stock returns in latin america. Emerging Markets Review 10(4), 331 - 344.

Arghyrou, M. G. and A. Kontonikas (2012). The EMU sovereign-debt crisis: Fundamentals, expectations and contagion. Journal of International Financial Markets, Institutions and Money 22(4), 658-677.

Arouri, M. E. H., D. K. Nguyen, and K. Pukthuanthong (2012). An international CAPM for partially integrated markets: Theory and empirical evidence. Journal of Banking \& Finance 36(9), 2473-2493.

Aruga, K. and S. Managi (2011). Tests on price linkage between the U.S. and Japanese gold and silver futures markets. Economics Bulletin 31(2), $1038-1046$. 
Asness, C., A. Berger, and C. Palazollo (2009). The Limits of Convertible Bond Arbitrage: Evidence from the Recent Crash. The Research Foundation of the CFA Institute.

Baele, L., A. Ferrando, P. Hördahl, E. Krylova, and C. Monnet (2004). Measuring European Financial Integration.

Bakshi, G. and D. Madan (2006). A theory of volatility spreads. Management Science 52(12), 1945-1956.

Ballester, L., B. Casu, and A. González-Urteaga (2016). Bank fragility and contagion: Evidence from the bank CDS market. Journal of Empirical Finance 38(A), 394-416.

Ballester Miquel, L., A. González-Urteaga, and D. Tudela Ferrándiz (2014). Credit risk transmission in the European banking sector: the case of the subprime and Eurozone debt crises. Spanish Journal of Finance and Accounting 43(4), 449-472.

Barari, M. (2004). Equity market integration in latin america: A timevarying integration score analysis. International Review of Financial Analysis 13, 649-668.

Bartram, S. M., G. W. Brown, and B. A. Minton (2010). Resolving the exposure puzzle: The many facets of exchange rate exposure. Journal of Financial Economics 95(2), 148-173.

Basel Committee on Banking Supervision (2013a). Basel III: The Liquidity Coverage Ratio and liquidity risk monitoring tools.

Basel Committee on Banking Supervision (2013b). Global systemically important banks: updated assessment methodology and the higher loss absorbency requirement.

Batten, J. A., C. Ciner, and B. M. Lucey (2010). The macroeconomic determinants of volatility in precious metals markets. Resources Policy 35(2), 65-71.

Batten, J. A., I. Loncarski, and P. G. Szilagyi (2013). Recent cross-border banking within Europe: International balance sheet perspectives, Chapter 1, pp. 15-30. 
Baur, D. G. and B. M. Lucey (2009). Flights and contagionan empirical analysis of stockbond correlations. Journal of Financial Stability 5(4), $339-352$.

Bedendo, M. and P. Colla (2015). Sovereign and corporate credit risk: Evidence from the eurozone. Journal of Corporate Finance 33(1), 34-52.

Bekaert, G. and C. R. Harvey (1995). Time-varying world market integration. The Journal of Finance 50, 403-444.

Bekaert, G. and C. R. Harvey (2003). Emerging markets finance. Journal of Empirical Finance 10(1), 3 - 55. Emerging Markets S.I.

Bekaert, G., C. R. Harvey, C. T. Lundblad, and S. Siegel (2011). What segments equity markets? The Review of Financial Studies 24(12), 38413890 .

Bekaert, G. and R. Hodrick (1992). Characterizing predictable components in excess returns on equity and foreign exchange markets.

Berger, D. and K. Pukthuanthong (2012). Market fragility and international market crashes. Journal of Financial Economics 105(3), 565 - 580.

Bernard, A. (1991). Empirical implications of the convergence hypothesis. CEPR Working Papers.

Berrill, J., B. M. Lucey, and M. O'Hagan-Luff (2017). Does Firm Internationalisation Matter to Investors When Markets are Declining?

Bessembinder, H. and K. Chan (1992). Time-varying risk premia and forecastable returns in futures markets. Journal of Financial Economics 32(2), 169-193.

Bessler, D. A. and J. Yang (2003). The structure of interdependence in international stock markets. Journal of International Money and Finance 22(2), $261-287$.

Bilson, C. M., T. J. Brailsford, and V. C. Hooper (2002). The explanatory power of political risk in emerging markets. International Review of Financial Analysis 11(1), 1 - 27. 
Birg, G. and B. Lucey (2006). Integration of smaller european equity markets: A time-varying integration score analysis. IIIS Discussion Paper No. 136.

Blanco, R., S. Brennan, and I. Marsh (2005). An empirical analysis of the dynamic relationship between investment grade bonds and credit default swaps. Journal of Finance 60, 2255-2281.

Boeh, K. K. and C. Southam (2011). Impact of initial public offering coalition on deal completion. Venture Capital 13(4), 313-336.

Brennan, M. (1958). The supply of storage. American Economic Review 48, $50-72$.

Bris, A. and C. Cabolis (2008). The Value of Investor Protection: Firm Evidence from Cross-Border Mergers. The Review of Financial Studies 21(2), 605-648.

Brire, M., K. Oosterlinck, and A. Szafarz (2015). Virtual currency, tangible return: Portfolio diversification with bitcoin. Journal of Asset Management 16, 365-373.

Brooks, R. and M. Del Negro (2004). The rise in comovement across national stock markets: market integration or IT bubble? Journal of Empirical Finance 11(5), 659-680.

Brunnermeier, M. K. (2009). Deciphering the liquidity and credit crunch 2007-2008. The Journal of economic perspectives 23(1), 77-100.

Bunda, I., A. J. Hamann, and S. Lall (2009). Correlations in emerging market bonds: The role of local and global factors. Emerging Markets Review 10(2), 67 - 96.

Busaba, W. Y., L. M. Benveniste, and R.-J. Guo (2001). The option to withdraw IPOs during the premarket: empirical analysis. Journal of Financial Economics 60, 73-102.

Cai, Y., R. Y. Chou, and D. Li (2009). Explaining international stock correlations with CPI fluctuations and market volatility. Journal of Banking \& Finance 33(11), 2026-2035. 
Campbell, J. Y. and Y. Hamao (1992). Predictable stock returns in the united states and japan: A study of longterm capital market integration. Journal of Finance 47, 43-70.

Caporin, M., L. Pelizzon, F. Ravazzolo, and R. Rigobon (2013). Measuring sovereign contagion in europe. NBER Working Paper No. 18741.

Cappiello, L., R. F. Engle, and K. Sheppard (2006). Asymmetric dynamics in the correlations of global equity and bond returns. Journal of Financial Econometrics 4(4), 537.

Carrieri, F., V. Errunza, and K. Hogan (2007). Characterizing world market integration through time. The Journal of Financial and Quantitative Analysis 42(4), 915-940.

Cashin, P., J. McDermott, and A. Scott (1999). The myth of co-moving commodity prices. IMF Working Paper 99/169.

Chambet, A. and R. Gibson (2008). Financial integration, economic instability and trade structure in emerging markets. Journal of International Money and Finance $27(4), 654-675$.

Chari, A., P. P. Ouimet, and L. L. Tesar (2010). The Value of Control in Emerging Markets. The Review of Financial Studies 23(4), 1741-1770.

Cheah, E. and J. Fry (2015). Speculative bubbles in bitcoin markets? an empirical investigation into the fundamental value of bitcoin. Economics Letters 130, 32-36.

Cheng, I.-H. and W. Xiong (2014). Financialization of commodity markets. Annual Review of Financial Economics 6(1), 419-441.

Christiansen, C. (2014). Integration of european bond markets. Journal of Banking and Finance 42, 191 - 198.

Coelho, R., C. G. Gilmore, B. M. Lucey, P. Richmond, and S. Hutzler (2007). The evolution of interdependence in world equity marketsevidence from minimum spanning trees. Physica A: Statistical Mecahnics and its Applications 376, 455466. 
Connolly, R., C. Stivers, and L. Sun (2005). Stock market uncertainty and the stock-bond return relation. The Journal of Financial and Quantitative Analysis 40(1), 161-194.

Cordella, T. and A. Ospino Rojas (2017). Financial globalization and market volatility : an empirical appraisal. Policy Research working paper; no. WPS 8091. Washington, D.C. : World Bank Group.

Cotei, C. and J. B. Farhat (2009). The Trade-Off Theory and the Pecking Order Theory: Are They Mutually Exclusive? Available at SSRN.

De Nicola, F., P. De Pace, and M. Hernandez (2014). Co-Movement of major commodity price returns: Time series assessment. World Bank Policy Research Working Paper No. 6845.

De Santis, R. (2016). Market sentiment, economic activity and fragmentation. ECB, Working Paper No.1930.

Degryse, H. and S. Ongena (2004). The impact of technology and regulation on the geographical scope of banking. Oxford Review of Economic Policy 20(4), 571-590.

Delatte, A., M. Gex, and A. López-Villavicencio (2012). Has the cds market influenced the borrowing cost of european countries during the sovereign crisis. Journal of International Money and Finance 31, 481-497.

Denis, D. J., D. K. Denis, and K. Yost (2002). Global Diversification, Industrial Diversification, and Firm Value. The Journal of Finance 57(5), 1951-1979.

Diamond, D. W. and R. Rajan (2009). The credit crisis: conjectures about causes and remedies. American Economic Review 99, 606-610.

Diamonte, R. L., J. M. Liew, and R. L. Stevens (1996). Political Risk in Emerging and Developed Markets. Financial Analysts Journal 52(3), 7176.

Diebold, F., L. Liu, and K. Yilmaz (2017). Commodity connectedness. PIER Working Paper 17-03. 
Diebold, F. X. and K. Yilmaz (2015). Financial and Macroeconomic Connectedness: A Network Approach to Measurement and Monitoring (1st ed.). Oxford University Press, USA.

Dieckmann, S. and T. Plank (2012). Default risk of advanced economies: An empirical analysis of credit default swaps during the financial crisis. Review of Finance 16, 903-934.

Dimic, N., J. Kiviaho, V. Piljak, and J. Aijo (2016). Impact of financial market uncertainty and macroeconomic factors on stockbond correlation in emerging markets. Research in International Business and Finance 36, $41-51$.

Dimic, N., V. Orlov, and V. Piljak (2015). The political risk factor in emerging, frontier, and developed stock markets. Finance Research Letters 15, $239-245$.

Doukas, J. and N. G. Travlos (1988). The Effect of Corporate Multinationalism on Shareholders' Wealth: Evidence from International Acquisitions. The Journal of Finance 43(2), 1161-1175.

Drobetz, W. and R. Fix (2005). What are the Determinants of the Capital Structure? Evidence from Switzerland. Swiss Journal of Economics and Statistics 141(1), 71-113.

Dudley, W. C. (2017). Reforming Culture for the Long Term.

Duffie, D. (2008). Derivatives and mass financial destruction. The Wall Street Journal 22.

Duijm, P. and D. Schoenmaker (2017). European Banks Straddling Borders: Risky or Rewarding? Presented at INFINITI 2017.

Dumas, B., C. R. Harvey, and P. Ruiz (2003). Are correlations of stock returns justified by subsequent changes in national outputs? Journal of International Money and Finance 22(6), 777 - 811.

Dunbar, C. G. and S. R. Foerster (2008). Second time lucky? Withdrawn IPOs that return to the market. Journal of Financial Economics 87(3), 610-635. 
Dwyer, G. P. (2014). The economics of bitcoin and similar private digital currencies. Journal of Financial Stability 17, 81-91.

Dyhrberg, A. H. (2016). Bitcoin, gold and the dollar - A GARCH volatility analysis. Finance Research Letters 16, 85-92.

Eckbo, B. E. (2009). Bidding strategies and takeover premiums: A review. Journal of Corporate Finance 15(1), 149-178.

Emter, L., M. Schmitz, and M. Tirpak (2017). Cross-border Banking in Europe after the crisis: What explains the Great Retrenchment? Presented at INFINITI 2017.

Engelen, P. J. and M. van Essen (2010). Underpricing of IPOs: Firm-, issue- and country-specific characteristics. Journal of Banking and Finance 34 (8), 1958-1969.

Erb, C. B., C. R. Harvey, and T. E. Viskanta (1996). Political Risk, Economic Risk, and Financial Risk. Financial Analysts Journal 52(6), 29-46.

Erb, C. B., H. C. R. and T. E. Viskanta (1996). Expected returns and volatility in 135 countries. Journal of Portfolio Management 22(3), 4658.

Errunza, V. R., L. E. and P. Padmanabhan (1992). Tests of integration, mild segmentation and segmentation hypotheses. Journal of Banking and Finance 16, 949-972.

European Commission (2013). Communication from the Commission on the application, from 1 August 2013, of State aid rules to support measures in favour of banks in the context of the financial crisis ("Banking Communication"). Official Journal of the European Union 30(7).

Fama, E. F. and K. R. French (2002). Testing Trade-Off and Pecking Order Predictions about Dividends and Debt. The Review of Financial Studies 15(1), 1-33.

Farooqi, J., D. Huerta, and T. Ngo (2015). Should you globally diversify or let the globally diversified firm do it for you? The Quarterly Review of Economics and Finance 57, 75-85. 
Fecht, F., H. P. Grüner, and P. Hartmann (2012). Financial integration, specialization, and systemic risk. Journal of International Economics 88(1), $150-161$.

Fernandez, V. (2015a). Commodity price excess co-movement from a historical perspective: 1900-2010. Energy Economics 49, 698-710.

Fernandez, V. (2015b). Influence in commodity markets: Measuring comovement globally. Resources Policy 45, 151-164.

Fillat, J. L., S. Garetto, and L. Oldenski (2015). Diversification, cost structure, and the risk premium of multinational corporations. Journal of International Economics 96(1), 37-54.

Forbes, K. J. and R. Rigobon (2002). No contagion, only interdependence: measuring stock market comovements. Journal of Finance 57(5), 22232261.

Forte, S. and J. I. Peña (2009). Credit spreads: An empirical analysis on the informational content of stocks, bonds, and CDS. Journal of Banking 8 Finance 33(11), 2013-2025.

Friedman, M. (1970). The Social Responsibility of Business is to Increase its Profits. The New York Times Magazine September(13).

Fry, J. and E. T. Cheah (2016). Negative bubbles and shocks in cryptocurrency markets. International Review of Financial Analysis 47, 343-352.

Fukuyama, F. (1995). Trust: The social virtues and the creation of prosperity. Number D10 301 c. 1/c. 2. Free Press Paperbacks.

Garmaise, M. (2000). Informal investors and the financing of entrepreneurial projects.

Ge, J., X. Wang, Q. Guan, W. Li, H. Zhu, and M. Yao (2016). World rare earths trade network: Patterns, relations and role characteristics. Resources Policy 50, 119-130.

Gilchrist, S. and E. Zakrajsek (2012). Credit spreads and business cycle fluctuations. American Economic Review 102, 1692-1720. 
Gilmore, C. G. and G. M. McManus (2002). International portfolio diversification: US and Central European equity markets. Emerging Markets Review 3(1), 69-83.

Goergen, M., A. Khurshed, and L. Renneboog (2009). Why are the French so different from the Germans? Underpricing of IPOs on the Euro New Markets. International Review of Law and Economics 29(3), 260-271.

Gogolin, F., M. M. Dowling, and M. Cummins (2017). Individual values and household finances. Applied Economics 49(35), 3560-3578.

Gogolin, F. and F. Kearney (2016). Does speculation impact what factors determine oil futures prices? Economics Letters 144, 119-122.

Goodell, J. W. (2017). Trust and governance: The conditioning role of national culture. Finance Research Letters.

Graham, M. and J. Nikkinen (2011). Co-movement of the finnish and international stock markets: a wavelet analysis. The European Journal of Finance 17(5-6), 409-425.

Greenberg, M. (2010). Prime brokers and derivatives dealers. Squam Lake Working Group on Financial Regulation Working Paper, April.

Groba, J., J. A. Lafuente, and P. Serrano (2013). The impact of distressed economies on the eu sovereign market. Journal of Banking and Finance 37, $2520-2532$.

Groh, A. P., H. von Liechtenstein, and K. Lieser (2010). The European Venture Capital and Private Equity country attractiveness indices. Journal of Corporate Finance 16, 205-224.

Guo, F., C. R. Chen, and Y. S. Huang (2011). Markets contagion during financial crisis: A regime-switching approach. International Review of Economics and Finance 20, 95-109.

Haiss, P. R. and B. Sammer (2010). The impact of derivatives markets on financial integration, risk, and economic growth.

Hardouvelis, G. A., D. Malliaropulos, and R. Priestley (2006). EMU and European equity market integration. The Journal of Business 79(1), 365392. 
Hart, O. (2001). Financial contracting. journal of Economic Literature 39, 1079-1100.

Helbing, P. and B. Lucey (2017). The Determinants of IPO Withdrawal Evidence from Europe. Working Paper.

Hkiri, B., H. S. A. C. and L. Yarovaya (2017). Are islamic indexes a safe haven for investors? an analysis of total, directional and net volatility spillovers between conventional and islamic indexes and importance of crisis periods. Pacific-Basin Finance Journal 43, 124-150.

Honohan, P., D. Donovan, P. Gorecki, and R. Mottiar (2010). The Irish Banking Crisis: Regulatory and Financial Stability Policy. A Report to the Minister for Finance by the Governor of the Central Bank. Technical report, Central Bank of Ireland.

Hope, O.-K., W. Thomas, and D. Vyas (2011). The cost of pride: Why do firms from developing countries bid higher? Journal of International Business Studies 42(1), 128-151.

Horny, G., S. Manganelli, and B. Mojon (2016). Measuring Financial Fragmentation in the Euro Area Corporate Bond Market. Banque de France, Working Paper No.582.

Huizinga, H., J. Voget, and W. Wagner (2012). Who bears the burden of international taxation? Evidence from cross-border M\&As. Journal of International Economics 88(1), 186-197.

Hutson, E. and E. Laing (2014). Foreign exchange exposure and multinationality. Journal of Banking \& Finance 43, 97-113.

Hutson, E. and S. Stevenson (2010). Openness, hedging incentives and foreign exchange exposure: A firm-level multi-country study. Journal of International Business Studies 41(1), 105-122.

Ibrahim, B. M. and J. Brzeszczynski (2009). Inter-regional and region-specific transmission of international stock market returns: The role of foreign information. Journal of International Money and Finance 28(2), 322-343.

Ibrahim, B. M. and J. Brzeszczynski (2014). How beneficial is international stock market information in domestic stock market trading? The European Journal of Finance 20(3), 201-231. 
Ibrahim, B. M., J. Brzeszczyński, and A. Bhattacharjee (2017). Geographical Changes in Influence of Stock Trading Centres Around the 2007 Global Financial Crisis.

Irwin, S. H. and D. R. Sanders (2011). Index funds, financialization, and commodity futures markets. Applied Economic Perspectives and Policy 33(1), $1-31$.

James, E., K. McLoughlin, and E. Rankin (2014). Cross-border Capital Flows since the Global Financial Crisis. Reserve Bank of Australia Bulletin June 2014, 65-72.

Kalbaska, A. and M. Gatkowski (2012). Eurozone sovereign contagion: Evidence from the cds market (2005-2010). Journal Behavior and Organization 83, 657-673.

Kayhan, A. and S. Titman (2007). Firms' histories and their capital structures. Journal of Financial Economics 83(1), 1-32.

Kearney, C. and B. Lucey (2004). International equity market integration: Theory, evidence and implications. International Review of FInancial Analysis 13, 571-583.

Kearney, C. and V. Poti (2006). Correlation dynamics in european equity markets. Research in International Business and Finance 20 (3), 305-321.

Kenett, D., X. Huang, I. Vodenska, S. Havlin, and H. Stanley (2015). Partial correlation analysis: applications for financial markets. Quantitative Finance 15, 569-578.

Kim, S. J., F. Moshirian, and E. Wu (2005). Dynamic stock market integration driven by the european monetary union: An empirical analysis. Journal of Banking and Finance 29(10), 2475 - 2502.

Kim, S.-J., F. Moshirian, and E. Wu (2006). Evolution of international stock and bond market integration: Influence of the european monetary union. Journal of Banking and Finance 30(5), 1507 - 1534.

Kiviaho, J., J. Nikkinen, V. Piljak, and T. Rothovius (2014). The comovement dynamics of european frontier stock markets. European $\mathrm{Fi}$ nancial Management 20(3), 574-595. 
Krapl, A. A. (2015). Corporate international diversification and risk. International Review of Financial Analysis 37, 1-13.

Kumar, M. S. and T. Okimoto (2011). Dynamics of international integration of government securities markets. Journal of Banking and Finance 35(1), $142-154$.

Lagoarde-Segot, T. and B. M. Lucey (2006). Equity Markets and Economic Development: What Do We Know? Available at SSRN.

Laing, E., B. M. Lucey, and T. Leutkemeyer (2017). Commodity exposure, financial and operational hedging of us oil and gas companies.

Lane, P. R. and G. M. Milesi-Ferretti (2017). International Financial Integration in the Aftermath of the Global Financial Crisis. IMF Working Paper.

Lau, M. C. K., S. A. Vigne, S. Wang, and L. Yarovaya (2017). Return Spillovers Between White Precious Metal ETFs: The Role of Oil, Gold, and Global Equity. International Review of Financial Analysis 52, 316332 .

Leary, M. T. and M. R. Roberts (2010). The pecking order, debt capacity, and information asymmetry. Journal of Financial Economics 95(3), 332355 .

Lehkonen, H. (2015a). Stock market integration and the global financial crisis. Review of Finance 19(5), 2039.

Lehkonen, H. (2015b). Stock Market Integration and the Global Financial Crisis. Review of Finance 19(5), 2039-2094.

Lehkonen, H. and K. Heimonen (2015). Democracy, political risks and stock market performance. Journal of International Money and Finance 59, 77 -99 .

Lescaroux, F. (2009). On the excess co-movement of commodity prices. A note about the role of fundamental factors in short-run dynamics. Energy Policy 37, 3906-3913.

Lhabitant, F.-S. (2004). Hedge funds: Quantitative insights (1th ed.). John Wiley \& Sons. 
Litvack, L. and S. A. Vigne (2017). Demonetisation in India and Emerging Challenges. Belfast: Queen's University Press.

Longin, F. and B. Solnik (1995). Is the correlation in international equity returns constant: 1960-1990. Journal of International Money and Finance 14(1), 3-26.

Longin, F. and B. Solnik (2001). Extreme correlation of international equity markets. The Journal of Finance 56(2), 649-676.

Lucey, B. and A. Sevic (2010). Investigating the Determinants of Banking Coexceedances in Europe in the Summer of 2008. Journal of International Financial Markets, Institutions and Money, 20(3), 275-283.

Lucey, B. M., S. S. Sharma, and S. A. Vigne (2016). Gold and inflation(s) A time-varying relationship. Economic Modelling.

Lucey, B. M. and J. Steeley (2006). Measuring and assessing the effects and extent of international bond market integration. Journal of International Financial Markets, Institutions and Money 16(1), 1-3.

Luo, Y., S. Tanna, and G. De Vita (2016). Financial openness, risk and bank efficiency: Cross-country evidence. Journal of Financial Stability 24, $132-148$.

Mancheri, N. and T. Marukawa (2016). Rare earth Elements: China and Japan in industry, trade, and value chain. ISS Contemporary Chinese Research Series No. 17.

McGee, R. J. and F. McGroarty (2017). The risk premium that never was: A fair value explanation of the volatility spread. European Journal of Operational Research 262(1), 370-380.

Merton, R. and Z. Bodie (1995). A conceptual framework for analyzing the financial environment. DB Crane e, KA Froot, SP Mason, AF Perold, $R C$ Merton. Cambridge, MA: Harvard Business School Press.

Minoiu, C., C. Kang, V. Subrahmanian, and A. Berea (2014). Does financial connectedness predict crises? Quantitative Finance 15(4), 607-624. 
Moeller, S. B., F. P. Schlingemann, and R. M. Stulz (2005). Wealth Destruction on a Massive Scale? A Study of Acquiring-Firm Returns in the Recent Merger Wave. The Journal of Finance 60(2), 757-782.

Murphy, K. J. (2013). Regulating banking bonuses in the european union: A case study in unintended consequences. European Financial Management 19(4), 631-657.

Murphy, R. P. (2009). Did deregulated derivatives cause the financial crisis.

Myers, S. C. (1984). The Capital Structure Puzzle. The Journal of Finance $39(3), 574-592$.

Natanelov, V., M. Alam, A. McKenzie, and G. Huylenbroeck (2011). On the excess co-movement of commodity prices. A note about the role of fundamental factors in short-run dynamics. Energy Policy 39, 4971-4984.

Neville, C. and B. M. Lucey (2017). The Capital Structure Conundrum: High Tech SMEs' Future Goals, Challenges \& Exports.

Nyberg, P. (2011). Misjudging Risk: Causes of the Systematic Banking Crisis in Ireland. Report of the Commission of Investigation into the Banking Sector in Ireland. Technical report.

O'Connor, F. A., B. M. Lucey, J. A. Batten, and D. G. Baur (2015). The financial economics of gold - A survey. International Review of Financial Analysis 41, 186-205.

Panchenko, V. and E. Wu (2009). Time-varying market integration and stock and bond return concordance in emerging markets. Journal of Banking and Finance 33(6), 1014 - 1021.

Perotti, E. C. and P. van Oijen (2001). Privatization, political risk and stock market development in emerging economies. Journal of International Money and Finance 20(1), 43 - 69.

Piljak, V. (2013). Bond markets co-movement dynamics and macroeconomic factors: Evidence from emerging and frontier markets. Emerging Markets Review 17, $29-43$.

Piljak, V. and L. Swinkels (2017). Frontier and emerging government bond markets. Emerging Markets Review 30, 232 - 255. 
Pindyck, R. and J. Rotemberg (1990). The excess co-movement of commodity prices. Economic Journal 100, 1173-1189.

Pozzi, L. and G. Wolswijk (2012). The time-varying integration of euro area government bond markets. European Economic Review 56(1), 36 - 53.

Pukthuanthong, K. and R. Roll (2009). Global market integration: An alternative measure and its application. Journal of Financial Economics 94(2), $214-232$.

Reddy, Y. (2002). Dimensions of financial development market reforms and integration: the indian experience. Macroeconomics and monetary policy: issues for a reforming economy. Oxford University Press, New Delhi.

Regling, K. and M. Watson (2010). A preliminary report on the sources of Ireland's banking crisis. Dublin: OH: Government Publications Office.

Rosati, P., M. Cummins, P. Deeney, F. Gogolin, L. van der Werff, and T. Lynn (2017). The effect of data breach announcements beyond the stock price: Empirical evidence on market activity. International Review of Financial Analysis 49, 146-154.

Sas, C. and I. E. Khairuddin (2017). Design for trust: An exploration of the challenges and opportunities of bitcoin users. In Proceedings of the 2017 CHI Conference on Human Factors in Computing Systems, pp. 6499-6510. ACM.

Saunders, A., R. C. Smith, and I. Walter (2009). Enhanced regulation of large, complex financial institutions. Financial Markets, Institutions $\mathscr{6}$ Instruments 18(2), 153-154.

Sheng, X., J. Brzeszczyski, and B. M. Ibrahim (2017). International stock return co-movements and trading activity. Finance Research Letters.

Sironi, A. (2003). Testing for market discipline in the European banking industry: evidence from subordinated debt issues. Journal of Money, Credit, and Banking 35(3), 443-472.

Smith, K. L. (2002). Government bond market seasonality, diversification, and cointegration: International evidence. Journal of Financial Research 25(2), 203-221. 
Syllignakis, M. N. and G. P. Kouretas (2011). Dynamic correlation analysis of financial contagion: Evidence from the central and eastern european markets. International Review of Economics and Finance 20(4), 717 732 .

Tykvova, T. and U. Walz (2007). How important is participation of different venture capitalists in German IPOs? Global Finance Journal 17(3), 350378.

United Nations (2012). World Investment Report. Technical report.

Urquhart, A. (2016). The inefficiency of bitcoin. Economics Letters 148, 80-82.

Vigne, S. A., B. M. Lucey, F. A. O'Connor, and L. Yarovaya (2017). The financial economics of white precious metals - A survey. International Review of Financial Analysis 52, 292-308.

Watson, M. (1999). Rethinking capital mobility, re-regulating financial markets. New Political Economy 4 (1), 55-75.

Westhead, P. and D. J. Storey (1997). Financial constraints on the growth of high technology small firms in the United Kingdom. Applied Financial Economics 7(2), 197-201.

Working, H. (1949). The theory of price of storage. The American Economic Review 39(6), 1254-1262.

Wu, W., M. C. K. Lau, and S. A. Vigne (2017). Modelling Asymmetric Conditional Dependence between Shanghai and Hong Kong Stock Markets. Research in International Business and Finance.

Yang, J. (2005). International bond market linkages: a structural var analysis. Journal of International Financial Markets, Institutions and Money 15(1), $39-54$.

Yang, J., Y. Zhou, and Z. Wang (2009). The stock-bond correlation and macroeconomic conditions: One and a half centuries of evidence. Journal of Banking and Finance 33(4), 670 - 680. 
Yarovaya, L., J. Brzeszczynski, and C. K. M. Lau (2016). Intra- and interregional return and volatility spillovers across emerging and developed markets: Evidence from stock indices and stock index futures. International Review of Financial Analysis 43, 96-114.

Yarovaya, L. and C. Lau (2016). Stock market comovements around the global financial crisis: Evidence from the uk, brics and mist markets. Research in International Business and Finance 37, 605619.

Zaghini, A. (2016). Fragmentation and heterogeneity in the euro-area corporate bond market: Back to normal? Journal of Financial Stability 23(1), $51-61$.

Zaghini, A. (2017). A tale of fragmentation: Corporate funding in the euroarea bond market. International Review of Financial Analysis 49(1), 5968. 